\title{
Birds in a vast arid upland: avian biogeographical patterns in the Pilbara region of Western Australia
}

\author{
Allan H. Burbidge ${ }^{1 *}$, R.E. Johnstone ${ }^{2}$ and David J. Pearson ${ }^{1}$ \\ ${ }^{1}$ Department of Environment and Conservation, PO Box 51, Wanneroo, Western Australia 6946, Australia. \\ ${ }^{2}$ Department of Terrestrial Zoology, Western Australian Museum, Locked Bag 49, Welshpool DC, \\ Western Australia 6986, Australia. \\ *Corresponding author: email: allan.burbidge@dec.wa.gov.au.
}

\begin{abstract}
We surveyed for the presence/absence of bird species at 297 sites, each of 16 ha, chosen to represent the geographical extent and diversity of terrestrial environments across the Pilbara biogeographic region, Western Australia. We recorded 132 species with an average of 19.1 species per site with a range from 3 to 49 . Sampling was carried out over a six-day period in each of two seasons, with visits of 0.5 to 1.0 hour to each site. The diurnal time of sampling at a site was varied in an effort to maximise the detection of species present.

Environments sampled included stony hills, slopes and plains, massive rocks and scree slopes, clay plains, saline muds, deep sands and riverine sites. Vegetation on most sites consisted of hummock grasslands of spinifex (Triodia spp.), usually with widely scattered shrubs or eucalypt trees, while sites on alluvial plains typically supported bunch grasses, saline flats had samphires, run-on areas in the southern Pilbara often supported stands of mulga, and riparian sites had vegetation varying from shrubs to gallery woodlands. Bird species richness was highest in riparian sites and lowest on samphire flats. Patterns in species composition were correlated with vegetation and substrate variables, including soil depth, ruggedness of the topography, soil chemistry and the presence of trees or shrubs. Variation partitioning of results from a PCNM analysis, however, indicated that only $7 \%$ of the observed variation in species composition could be attributed solely to the 25 environmental variables we measured, suggesting that much of the Pilbara is relatively uniform from the perspective of terrestrial birds. These results suggest that the existing conservation reserve system is likely to adequately conserve most of the variation in terrestrial bird communities in the Pilbara. However, riparian vegetation, with its distinctive bird assemblages, requires special conservation attention. These areas are of limited extent in the Pilbara and are subject to pressures such as degradation by domestic and feral stock grazing, weed invasion and disturbance by mining infrastructure and groundwater extraction.
\end{abstract}

\section{INTRODUCTION}

Biologists have long been interested in the evolution and biogeography of arid regions, and this has led to various studies and hypotheses about the way birds adapt to arid environments, particularly in relation to high temperatures, erratic rainfall and moisture availability (e.g. Serventy 1971; Fisher et al. 1972; Davies 1976; Main 1976; Schodde 1982; Withers and Williams 1990; Schleucher 1993; Tieleman et al. 2003; Byrne et al. 2008; Robin et al. 2009). Predictions concerning regional biogeographic patterning, however, have not been tested thoroughly. The Pilbara biogeographic region of north-western Australia is an arid environment where it is important to quantify assemblage composition and regional biogeographic patterns in order to guide conservation actions in the face of extensive and increasing economic and developmental pressures in the area.

The Pilbara has a subdued topography and most of the soils are rocky (Trendall et al. 1990; McKenzie et al. 2009). Its ancient landscapes are formed on rock strata dating from Archaean times, making them some of the oldest rocks in Australia. The broad distribution patterns of individual species comprising its bird fauna are well known (Storr 1984; Barrett et al. 2003; R.E. Johnstone, A.H. Burbidge and J.C. Darnell, unpublished data) and there have been studies of species 
occurrence at many separate locations, primarily for environmental impact assessments (e.g. Johnstone 1983; How et al. 1991; Ninox Wildlife Consulting 1992). There have also been more detailed studies of a few individual species (e.g. Schleucher 1993; Davis and Burbidge 2008). However, there has been no systematic survey across the Pilbara to assess patterns of bird species occurrence in relation to vegetation, geomorphology, climate and soil variables that might be used to predict occurrence.

Because of the geology of the Pilbara Craton and adjacent offshore islands, the region is a major area for mineral, oil and gas resource developments, and such developments are spread across the region (Ruddock 1999; Ferguson and Ruddock 2001). Proposed developments undergo assessments to identify conservation values and the likely impacts of developments on such values. However, the implications of such impacts on birds or other organisms at a regional scale, and their significance, are difficult to assess because there is no objective framework within which to do so (Burbidge et al. 2006; McKenzie et al. 2009); the current study is intended to contribute to such a framework.

An important first step in conservation management of the region is to document the geographic distribution of plants and animals in the region and elucidate patterns of biological diversity (Caughley and Gunn 1996). The present study was undertaken as part of a broader investigation of biogeographic patterns in a range of plant and animal groups in the Pilbara region (McKenzie et al. 2009). In this paper, we explore geographic patterns in the communities of terrestrial birds, based on data from 297 sites distributed across the region. Specifically, we examine patterns of species richness, explore compositional variation among sample sites, provide an overview of the composition and distribution of species assemblages, and document relationships between assemblage composition and characteristics of the physical and biological environment.

In general, little is known about community structure or composition in the bird faunas of Australian arid lands. In Western Australia, species assemblage data have been published for various areas including the Great Victoria and Gibson Deserts (Pianka and Pianka 1970), Nullarbor (Burbidge et al. 1987), Eastern Goldfields (Dell and How 1988, 1992; McKenzie et al. 1992; Burbidge et al. 1995) and the Carnarvon Basin (Burbidge et al. 2000). Examples from other parts of arid Australia

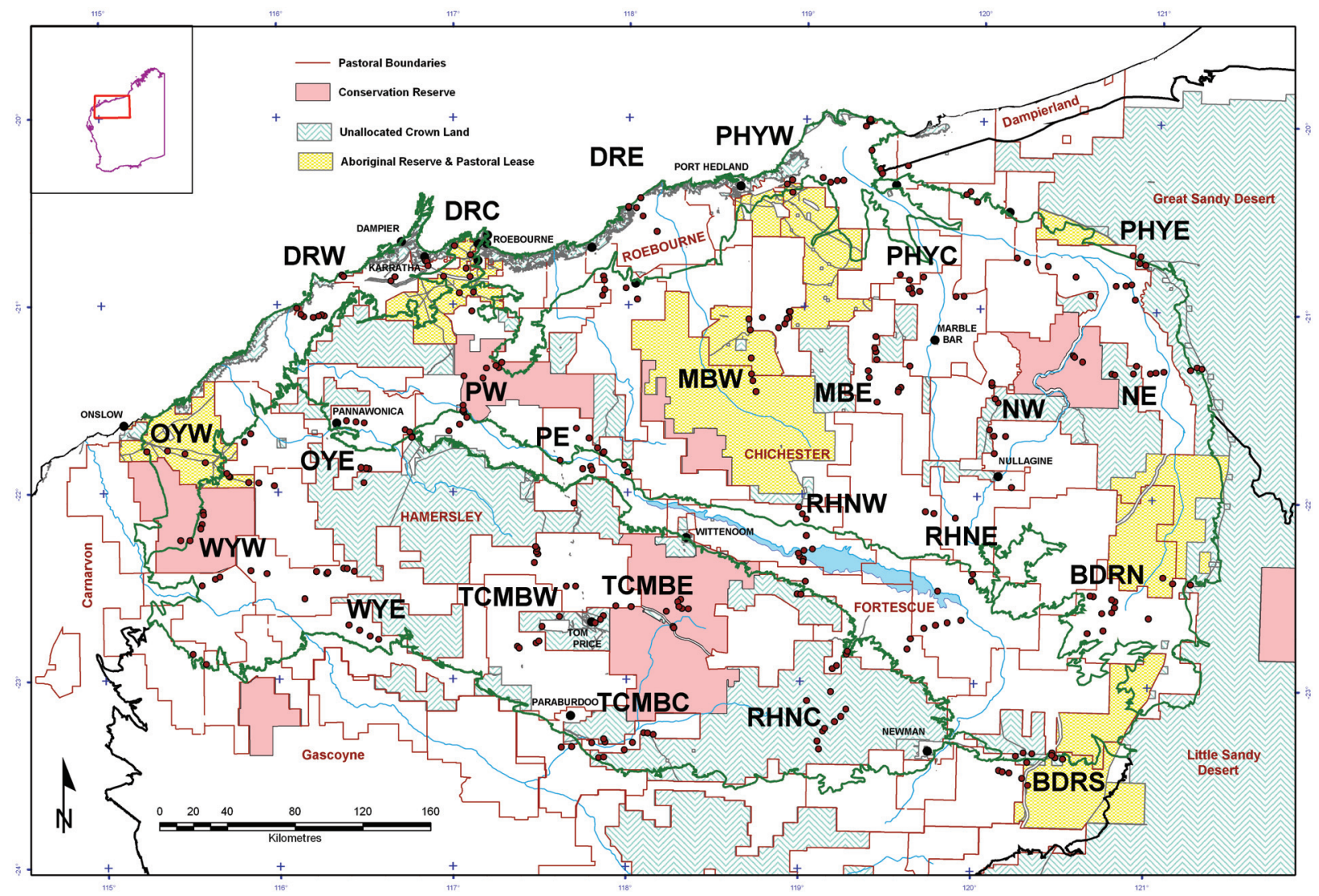

Figure 1 The Pilbara Biogeographic Region (Thackway and Cresswell 1995; Department of Environment Water Heritage and the Arts 2009) showing site locations, towns, main rivers (blue lines), land tenure, sub-regions (green lines) and surrounding regions (black lines). 
are few, but include studies from the Gawler and Everard Ranges, South Australia (Shurcliff 1980; Robinson et al. 1988) and from central Australia (e.g. Reid et al. 1993; Pavey and Nano 2009). Other authors (e.g. Gibson and Cole 1988) have described avian faunas on a land unit basis, as part of general biological survey work, while Landsberg et al. (1997) and Schneider and Griesser (2009) have described variation in avian communities in the vicinity of water points in various parts of the arid zone and Leavesley (2008) investigated the impact of fire on bird communities in mulga. Cody (1994) explored regional variation in bird communities in mulga, Recher and Davis (1997) described the foraging behaviour of birds in a mulga community in central Australia, while Paltridge and Southgate (2001) and Burbidge and Fuller (2007) documented variations in assemblages due to rainfall. While the overall composition of the Pilbara's bird fauna is reasonably well known, no previous study has examined patterns in community structure or composition.

At a regional scale, Gentilli (1992) noted an increase in bird species richness from east to west in the Pilbara and this appears consistent with the published maps from the two Birds Australia atlas data sets (Blakers et al. 1984; Barrett et al. 2003), although the trend is not clear. The Pilbara also has higher species richness than surrounding regions, in part because the bird fauna consists of both tropical and southern elements (e.g. Franklin et al. 2000). At the continental scale, Gentilli (1992) found significant correlations between species richness in $240 \times 240 \mathrm{~km}$ squares and vegetation ground cover, the heights of dominant plant species and the number of plant formations and major distinct associations, as well as the relative relief of the land. Taking the three vegetation factors together gave a correlation coefficient of 0.83 and $R^{2}=0.69$. Combining all four gave an $R$ of 0.84 and $R^{2}=0.71$. Gentilli (1992) found that rainfall was highly correlated with vegetation parameters, but vegetation was thought to provide a more proximate explanation. Similarly, recent work in central Australia has shown that bird species patterns in that area are correlated most strongly with vegetation variables (Pavey and Nano 2009).

In the arid central west of Western Australia, Burbidge et al. (2000) found that temperature variables (particularly maximum temperature and diurnal range), followed by precipitation and soil chemistry, were the environmental variables showing the strongest correlation with broad-scale patterns of species composition in the Carnarvon Basin (to the south of our Pilbara study region), although substrate and vegetation characteristics appeared to operate more strongly at a local scale. This is consistent with the work of Schodde
(1982), who noted changes in species richness and composition correlated with historical changes in temperature and precipitation across the Australian arid zone.

We hypothesised that avian species richness in the Pilbara would be correlated negatively with longitude, and positively with increasing complexity in vegetation structure, while species composition at the broad scale was expected to be related to temperature and precipitation, and at finer scales to substrate, with vegetation characteristics operating at both scales. In particular, avian community composition was expected to be related to the presence of Acacia, especially mulga ( $A$. aneura and related taxa) (Cody 1994), Triodia (Ford 1974) and to the presence of river gums (e.g. Johnstone et al. 2000). This study set out to test these hypotheses.

\section{METHODS}

The study area was the Pilbara IBRA biogeographic region of $179,000 \mathrm{~km}^{2}$ as defined by Thackway and Cresswell (1995) (Figure 1). The climate has been described in some detail by Leighton (2004) and summarised in McKenzie et al. (2009). Most of the annual rainfall comes from local thunderstorms and cyclonic events, mostly in the period December to March, although winter rain can occur in coastal areas. The higher rainfall areas in the southern Pilbara (Pannawonica-Tom Price area) and the cooler coastal areas have a semidesert tropical climate with 9-11 months of dry weather. The remainder of the Pilbara has a desert climate characterised by low rainfall, periodic droughts and generally higher temperatures.

The Pilbara is the most prominent mountainous area in Western Australia, reaching about 1200 $\mathrm{m}$ above sea level on the Hamersley Plateau but, due to its antiquity, has relatively subdued, mainly rocky topography, and is dissected by intermittently flowing river systems (Trendall et al. 1990; May and McKenzie 2003; McKenzie et al. 2009). The Chichester subregion, the largest of the Pilbara IBRA subregions, consists mainly of undulating Archaean granite and basalt plains, including significant areas of basaltic ranges, with drainage trending to the north. The Hamersley subregion, to the south, is an area of Proterozoic sedimentary ranges and plateaux, dissected by gorges that expose basalts, shales and dolerites. The Fortescue subregion, which separates the Chichester and Hamersley subregions, comprises alluvial plains and riverine habitats, while the coastal plains (Roebourne subregion) consist of Quaternary alluvial and older colluvial coastal and sub-coastal plains. Soils are generally extremely shallow except on the coastal plains and in the Fortescue valley. 
Beard (1975) produced broad-scale mapping of Pilbara vegetation, while Van Vreeswyk et al. (2004b) described 102 land systems, based on geomorphology and vegetation. Predominant vegetation formations are tree and shrub steppe with scattered Eucalyptus trees, Acacia shrubs and Triodia hummock grasses. Mulga (A. aneura) woodlands occur in valleys in the southern part of the study area, and short bunch grasslands occur on alluvial plains.

The most widespread land use is pastoralism, originally based on sheep, but now based almost entirely on cattle (Van Vreeswyk et al. 2004a, b). The greatest grazing impacts have occurred in the Fortescue and De Grey valleys and on the coastal plains. Other land uses and tenures include unallocated Crown land, Aboriginal lands and Reserves, and conservation reserves, with mining being widespread but with localised impact (McKenzie et al. 2009).

Sample sites (Figure 1) were selected as described in McKenzie et al. (2009). The study region was divided into 24 survey areas to sample its full geographic extent and likely environmental gradients. These survey areas were of similar size so that sampling was evenly dispersed across the study region. Between 11 and 13 sampling sites were selected in each survey area to represent its geomorphic profile (i.e. combination of geology and topographic position). There was some pseudoreplication within and between survey areas to allow for the internal heterogeneity of the stratification units and to minimise any analytical circularity introduced by the stratification. The sites chosen were the least disturbed examples we could find.

At each site, birds were recorded at an unbounded quadrat of about 16 ha. Quadrats were unbounded in the sense that they were not marked, but each was centred on a permanently marked botanical quadrat (McKenzie et al. 2009). Observers were asked to sample within the vegetation unit represented on the botanical quadrat, so sometimes this meant that the bird sampling quadrat was rectangular rather than square, for example in gallery woodlands where the occurrence of vegetation was linear.

Approximately half the sites were sampled in September-October 2004 and in May 2005. A second set was sampled in September-October 2005 and in May 2006, with extra observations in the northeastern Pilbara in October 2006, as part of this area was missed due to flooding in May 2006, and some sites (NE) were in drought conditions during earlier sampling. See McKenzie et al. (2009) for further details, including rainfall records during sampling. All sites were searched over 5-6 days in each sampling period except for October 2006, when single visits were made. Observers were rotated between sites between sampling sessions to reduce any effects of observer bias (Lindenmayer et al. 2009). The object of sampling was to determine broad-scale trends, and the number of visits we made should be adequate for such a purpose (Field et al. 2005). Repeat surveys were conducted at different times on different days to optimise the likelihood of encountering all the species using each site (Field et al. 2002). During each sampling period, each site was visited once early in the morning, and on one to several occasions at different times of day on different days. Each visit extended over 0.5 to 1.0 hour. The objective of sampling was to determine species presence/ absence at each site, by searching each one as exhaustively as possible during each sampling period (see Tyre et al. 2003).

While some sampling was undertaken at night, relatively few sites were sampled, mostly by aural survey, and the effort was not uniform across sites. Data for nocturnal species, therefore, were excluded. This was a consequence of many sites being remote from camps used by survey personnel and resultant safety concerns of travelling long distances on poor roads at night with the threat of collision with stock and kangaroos.

Variations in seasonal conditions are a challenge when sampling birds in arid or semi-arid environments (e.g. Paltridge and Southgate 2001; Maron et al. 2005), and is exacerbated by the high incidence of nomadism in the avifauna of the Australian arid zone (Davies 1984), at times resulting in massive changes in abundance at a given site (Robin et al. 2009). Such effects are more noticeable in abundance data than in presence-absence data, and may lead to significant differences at the individual site level through time, even when the overall assemblage composition does not differ significantly (Maron et al. 2005). No attempt was made to estimate species abundance, as reliable abundance measures require about an order of magnitude more effort to acquire and, in any case, are subject to significant stochastic and other variation, particularly in arid areas (Ives and Klopfer 1997; Paltridge and Southgate 2001; Maron et al. 2005; Alldredge et al. 2007; Robin et al. 2009). We therefore sampled for presence, not abundance, we sampled all sites at two times of year to minimise seasonal effects, and we ask questions at the regional, not local, scale. Results of similar surveys (e.g. Burbidge et al. 2000) and comparisons of different data sets (Vellend et al. 2008) suggest that this approach is valid and robust.

Sampling effectiveness for bird species was assessed using the Chao 2 and incidence-based estimator (ICE) in EstimateS v. 8.0 (Colwell 2006).

In any spatial data such as those collected here, it is possible that there may be some degree of spatial 
autocorrelation, i.e. locations close to each other have a tendency to exhibit more similar values (e.g. lists of species present) than those further apart (Borcard et al. 1992; Dormann et al. 2007). To test for the presence of spatial autocorrelation, we used PATN (Belbin 1989, 1991a) to generate an association matrix based on Euclidean distance between sites, and converted this to a linear vector. Similarly, we took the Bray-Curtis matrix (based on bird occurrences at the same sites) and converted this to a linear vector. Plotting one vector against the other provides a scatter plot (Figure 2) in which the slope of the line of best fit is a measure of correlation, with a slope of zero indicating a complete absence of correlation. For our data, this line was represented by the equation $\mathrm{Y}=0.64+0.00004 \mathrm{X}$, indicating a small but detectable degree of correlation. We tested the significance of this by utilising a randomisation test with 999 permutations in the RELATE module in PRIMER (Clarke and Gorley 2006). This indicated a significant correlation (rho $=0.039, P=0.009$ ). Examination of the scatter plot indicated that most effects of correlation would be expected at intersite distances of less than about $50 \mathrm{~km}$. In addition, sites a very long way apart $(>500 \mathrm{~km})$ were less similar than expected, presumably because such comparisons included sites at the extreme southwest of the study area where southern species are most likely to occur, and sites in the north-east where desert sand-dune assemblages are more likely to be encountered. As the effects were small, we did not correct for them in subsequent analyses, except for the PCNM analyses (see below). Instead, we relied on more stringent criteria for acceptance of significance of correlations between the biological data and the environmental parameters that we tested.

Certain species were recorded at only a single site. These species ('singletons') tended to be rare, under-sampled or cryptic species that are likely to be overlooked during brief sampling sessions. These species occurred randomly in the data set and contribute little to estimation of similarity between sites, or to the interpretation of pattern in the data, so they were excluded from further analyses. Furthermore, as mentioned above, nocturnal species were removed before analysis (Burbidge et al. 2000).

A cluster analysis technique was used to detect similarities between sites, using the computer package PATN (Belbin 1989, 1991a). Sites were classified in terms of presence or absence of bird species using the Czekanowski association measure (which is the form of the Bray-Curtis association measure for presence/absence data), followed by hierarchical agglomerative fusion classification (flexible UPGMA, beta $=-0.1$ ). This procedure is appropriate for ecological presence/absence data and is robust to variations in species abundance patterns and hence sampling efficiencies (Faith $e t$ al. 1987; Belbin 1991a). The significance of differences in environmental variables when partitioned according to site groups were tested using Kruskal-Wallis analyses in Statistica v. 7 (StatSoft, Tulsa, OK, U.S.A.).

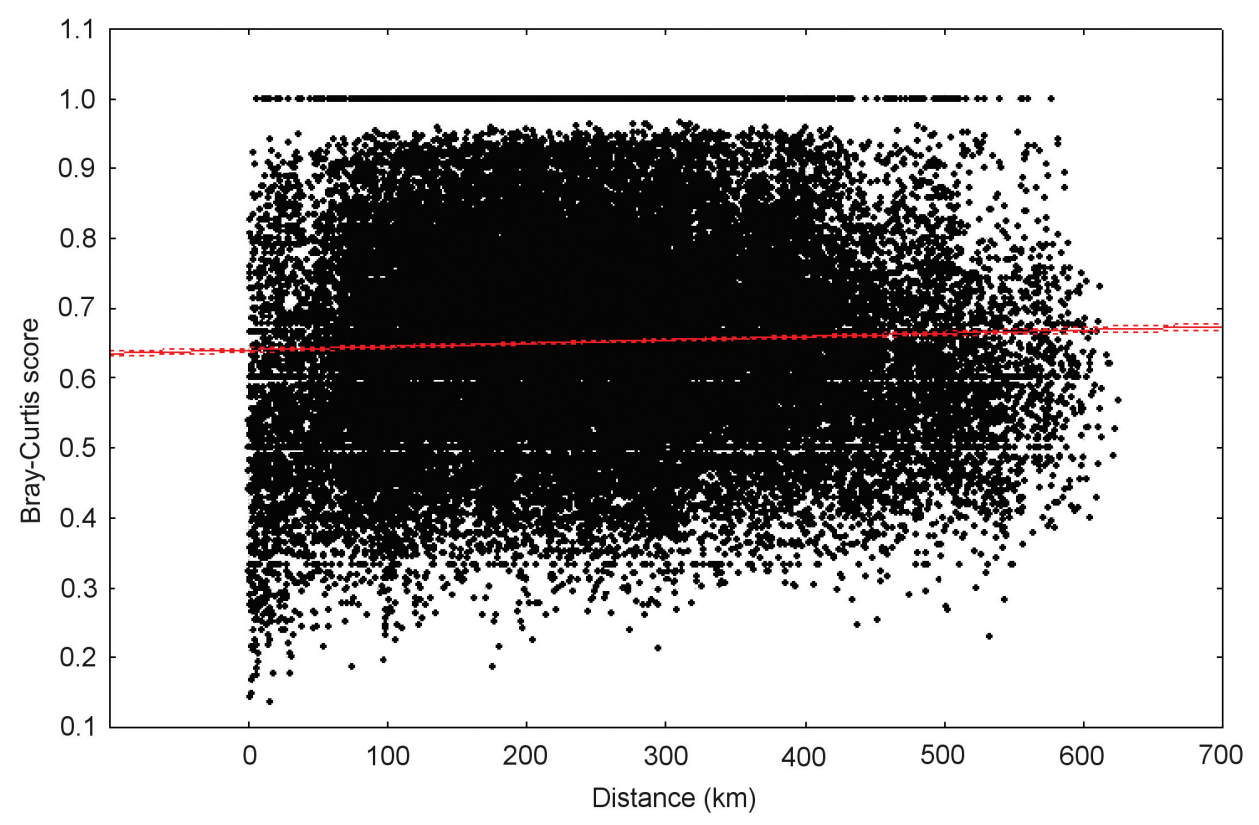

Figure 2 The relationship between Bray-Curtis scores of bird species occurrences and Euclidean distances between sampling sites, for 297 sites in the Pilbara region. A line of best fit with a slope of zero would indicate no correlation. The observed line of best fit $(Y=0.64+0.00004 \mathrm{X})$, and the occurrence of a few sites with low BrayCurtis scores at short distances, reveal a small degree of correlation suggesting a very weak effect between nearby sites. 
Table 1 Uncorrelated environmental variables, as used in analyses. Details in Methods and in McKenzie et al. (2009).

\begin{tabular}{|c|c|}
\hline Code & Attribute \\
\hline Tann & annual temperature \\
\hline PcoQ & precipitation in the coldest quarter \\
\hline Rug500 & $\begin{array}{l}\text { ruggedness, defined as the standard deviation of elevation within a } \\
500 \mathrm{~m} \text { radius }\end{array}$ \\
\hline SoilD & soil depth \\
\hline Asp & aspect \\
\hline Sun & sun index \\
\hline Outcrp & outcrops present \\
\hline Riv & distance to stream line \\
\hline Gcov & ground cover \\
\hline Dist to riparian & $\begin{array}{l}\text { distance to major riparian vegetation (Eucalyptus camaldulensis/E. } \\
\text { victrix and/or Melaleuca argentea) }\end{array}$ \\
\hline Sand & $\%$ sand \\
\hline EC & electrical conductivity \\
\hline $\mathrm{pH}$ & $\mathrm{pH}$ \\
\hline totP & total phosphorous \\
\hline totK & total potassium \\
\hline $\mathrm{P}$ & phosphorous \\
\hline exCa & exchangeable calcium \\
\hline exMg & exchangeable magnesium \\
\hline exNa & exchangeable sodium \\
\hline exK & exchangeable potassium \\
\hline \multicolumn{2}{|l|}{ Trees or mallees present } \\
\hline \multicolumn{2}{|c|}{ Eucalyptus camaldulensis and/or E. victrix present } \\
\hline \multicolumn{2}{|c|}{ Acacia sp. trees or shrubs present } \\
\hline \multicolumn{2}{|l|}{ Shrubs present } \\
\hline Hummock grass present & \\
\hline
\end{tabular}

The association matrix was also subjected to an ordination procedure to provide a second method of clustering sites. Sites located close together in ordination space will be similar in species composition. Ordination was carried out using the procedure SSH (semi-strong hybrid multidimensional scaling) (Belbin 1991b), which is robust to species richness effects. This was followed by principal axis rotation in order to maximise the variance on each axis.

Bird species were also classified in relation to the sites where they occurred. The two-step association measure of Belbin (1980) was used, since this measure is robust for use in situations such as ours where sites varied greatly in species richness (Austin and Belbin 1982). A two-way table was constructed from the classifications of sites and birds, in order to facilitate interpretation of both classifications.
Climatic, geomorphological and soil variables and a range of vegetation attributes were obtained from McKenzie et al. (2009). Other vegetation attributes were provided by S. van Leeuwen et al. (pers. comm.) and included ranked cover classes (1-5) of tree and shrub layers, together with cover values for hummock and tussock (perennial) and bunch (annual) grasses. The major tussock grass was introduced Buffel Grass (Cenchrus ciliaris). The number of layers of vegetation at each site was derived from these data. Structure was scored as follows: number of tree and shrub layers (scale $0-5)$, number of grass layers (scale 0-2; tussock and bunch combined), and total number of layers (0-7; trees, shrubs and grasses). Distance to a major riparian zone (i.e. known or presumed to contain tall trees of at least one of Eucalyptus camaldulensis, E. victrix or Melaleuca argentea) was measured in Google Earth. 
Grazing by cattle was not measured, as initial field inspections indicated that it was highly variable through time, and that cattle grazed everywhere except in very rocky areas, i.e. grazing intensity was correlated with landform.

Inter-correlations between measured variables were assessed using Pearson coefficients implemented in PRIMER (Clarke and Gorley 2006), and variables with resemblance greater than 0.70 were removed from the multivariate analyses, leaving 25 uncorrelated environmental variables (Table 1). The BEST routine in PRIMER (Clarke and Gorley 2006) was used to select the environmental variable subset that maximised rank correlation between matrices derived from bird occurrence and environmental variables.

These procedures identify apparent responses to gradients that may extend well beyond the study area (e.g. annual rainfall). In addition, we subjected the data set to eigenfunction analysis using principal coordinates of neighbour matrices (PCNM) in an effort to partition the variation in the Bray-Curtis site matrix between spatial and environmental sources, and to identify finer scale gradients, should they occur (Borcard et al. 2004). This analysis was done utilising the $R$ statistical language ( $\mathrm{R}$ Development Core Team 2009) with library PCNM (Legendre et al. 2009) using procedures developed by Borcard et al. (2004) and Dray et al. (2006). Because significant linear spatial trends were apparent in many of the bird species, the data were detrended before PCNM analysis. Significant PCNM eigenfunctions were identified using forward selection and, once the significant canonical axes were derived, we fitted linear models to these axes to determine which environmental attributes were associated with each axis. First, we regressed each axis on each environmental variable, one variable at a time. For a given axis, any variable with $P>0.15$ was eliminated from further consideration, leaving 9 environmental variables associated with axis 1, 14 with axis 2, 10 with axis 3 and 11 with axis 4 . For each of these axes we then carried out a multiple stepwise regression with backward selection using AIC as a criterion for inclusion.

Bird species nomenclature in this report is based on that used by the Western Australian Museum (Johnstone 2001, 2008).

\section{RESULTS}

A total of 132 bird species (69 passerines, 63 nonpasserines) was recorded at the 297 sites, resulting in a total of 5687 species by site intersections in the data matrix. Species richness across all sites varied from 3 to 49 (mean 19.1 $\pm 9.0 S D$ ). A few of the birds we recorded were waterbirds, as some of our sites had pools at the time of sampling. If waterbirds are excluded, we recorded 116 species, which is $81 \%$ of the 143 terrestrial bird species recorded from the Pilbara, including casual visitors and vagrants (R.E. Johnstone, A.H. Burbidge and J.C. Darnell, unpublished data). The ICE procedure in EstimateS produced an estimate of 143 species for the 297 sites, while the Chao 2 procedure produced an estimate of 139 species. Once nocturnal species were removed, this left 128 species observed, and 139 (ICE) and 135 (Chao2) estimated. Thus $92-95 \%$ of the total estimated richness across the range of Pilbara environments was revealed by our sampling program. The accumulation curves were close to asymptotic, with fewer than 0.5 species being added over the last 20 sites. Of the 132 species, 15 were recorded at a single site, while only two species were recorded at more than 200 sites (Zebra Finch at 244, and Singing Honeyeater at 231). All species recorded, and the number of sites where they were recorded, are listed in Appendix 1 , and the site by species matrix is provided as an accessory downloadable file. When singleton and nocturnal species were removed from the data set, 111 species remained and were included in the pattern analyses.

\section{Species richness}

In our data set, there was only a weak relationship between species richness and longitude $\left(\mathrm{Y}=0.318 \mathrm{X}-20.30\right.$ with $R^{2}=0.004$ for sites; $\mathrm{Y}=0.425 \mathrm{X}+11.57$ with $R^{2}=0.004$ for cells) or latitude $\left(\mathrm{Y}=3.075 \mathrm{X}-49.81\right.$ with $R^{2}=0.114$ for sites; $\mathrm{Y}=3.822 \mathrm{X}-21.52$ with $R^{2}=0.112$ for cells), although there was a slight trend towards higher species richness in the south. When sites were broadly categorised by substrate (McKenzie

Table 2 Species richness of diurnal birds at sites with and without trees. River gums included Eucalyptus camaldulensis and E. victrix. Data entries consist of mean, standard deviation and sample size. Significance levels are based on two-sample t-tests.

\begin{tabular}{llll} 
& Eucalyptus/Corymbia & River gums & Acacia \\
\hline With & $20.2 \pm 9.2(111)$ & $27.7 \pm 9.6(23)$ & $21.9 \pm 8.2(52)$ \\
Without & $15.7 \pm 7.0(186)$ & $16.5 \pm 7.4(274)$ & $16.4 \pm 7.8(245)$ \\
Significance level & $P<0.001$ & $P<0.001$ & $P<0.001$ \\
\hline
\end{tabular}


et al. 2009), there was little difference in bird species richness across these broad types, with rocky substrates having a mean of $16.4 \pm 7.5 S D$ $(\mathrm{n}=133)$, sandy $16.8 \pm 7.6(\mathrm{n}=48)$ and clayey sites $18.7 \pm 9.0(\mathrm{n}=116)$. However, there were significant differences in species richness across landforms $(\mathrm{H}=36.45$ adjusted for ties; $P<0.001$ ) (Figure 3). Not surprisingly, lowest species richness was on saline muds with samphire, and highest species richness was observed at riverine and claypan sites, presumably as a response to the presence of tall trees of at least one of Eucalyptus camaldulensis, E. victrix or Melaleuca argentea at almost all these sites, and two tree layers at most sites. Also not surprisingly, there were significant differences in species richness between sites with and without trees (Table 2), with the greatest difference being between sites with or without river gums ( $E$. camaldulensis and E. victrix).

We found only very weak correlation between topographic relief and species richness: fivecategory outcrop classification $(Y=-0.23+17.6 X$; $\left.R^{2}=0.002\right)$, elevation $\left(\mathrm{Y}=0.01+14.2 \mathrm{X} ; R^{2}=0.07\right)$ or ruggedness $\left(\mathrm{Y}=0.01+17.9 \mathrm{X}, R^{2}=0.0001\right)$.

\section{Site classification}

Seven groups were recognisable in the classification of sites. At this level, significant differences in environmental values were apparent between sites. The most highly significant were vegetation variables, while topography and soil variables were also correlated with the partition structure (Table 3). The BEST routine identified two sets of five environmental variables that showed the highest correlation $\left(R^{2}=0.324\right)$ with the 297 site Bray-Curtis site matrix. The first set included soil depth (soilD), ruggedness (Rug500), exchangeable magnesium (exMg), Tree or mallee present, and Acacia trees or shrubs present. The second set was similar except that Sand was included rather than soilD. Interestingly, both sets included topographic, soil and vegetation variables, but not climatic ones.

The major split in the dendrogram (Figure 4) was between the 251 'typical' Pilbara sites in Groups 1 and 2, and the remaining 46 sites in Groups 3-7. Sites in Groups 3-7 were, on average, further north than sites in Groups 1 and 2 and had greater soil depth with higher nutrient levels. These sites were less likely to support hummock grasses, shrubs or trees, and were in less rugged locations (Table 4).

The next highest split in the dendrogram separated Groups 3-5 and Groups 6-7. These groupings were correlated with vegetation structure; trees or mallees were much more frequently recorded in Groups 6 and 7 than in Groups 3-5 (Table 4).

While both Group 1 and Group 2 sites were widespread in the Pilbara (see Figure 5), Group

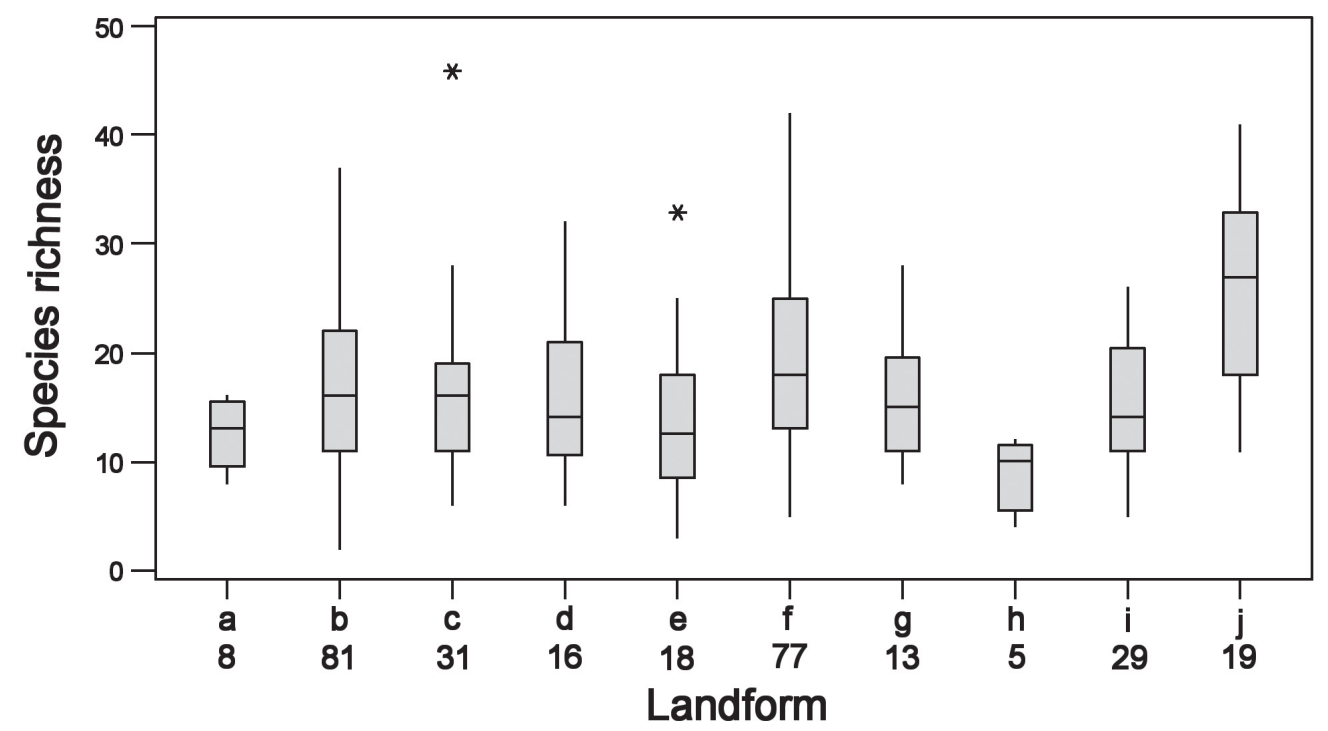

Figure 3 Bird species richness by landform category in the Pilbara region. Asterisks represent possible outliers. Key to categories: $\mathrm{a}=$ granite hills; $\mathrm{b}=$ massive rocks of hilltops and scree slopes; $\mathrm{c}=$ flat stony uplands, slopes and plains with shallow soils $(<0.5 \mathrm{~m})$ over pavement or hardpan; $\mathrm{d}=$ calcrete or opaline hills and mesas; $\mathrm{e}=$ heavy cracking/heaving clay plains and gentle slopes; $\mathrm{f}=$ deep clayey profiles, often with surface strew and/or stony profile; $g$ = granite slopes or plains with gritty clay profiles mantling sheet granite at depth; $h$ $=$ saline mud with samphire, sometimes mixed with Buffel or Triodia spp. where thin sandy surfaces were present; $i$ = deep sand and/or lightly sandy-clay soils as dunes and plains, desert as well as beach sands; $j$ = riverine levees, riverine beds, or clay pans with River Gums and/or paperbark trees. Numbers along the xaxis are the number of sites in each category. For further details of landforms see McKenzie et al. (2009). 
Table 3 Differences in some of the environmental variables (see Table 1) between site groups. The number after each variable is the Kruskal-Wallis value; only values with $P<0.001$ are shown.

\begin{tabular}{|c|c|c|c|c|c|c|c|}
\hline Group & 1 & 2 & 3 & 4 & 5 & 6 & 7 \\
\hline Number of sites & 117 & 134 & 21 & 15 & 4 & 4 & 2 \\
\hline $\begin{array}{l}\text { Latitude } \\
89.54\end{array}$ & $22.4 \pm 0.83$ & $21.5 \pm 0.71$ & $21.5 \pm 0.78$ & $20.7 \pm 0.63$ & $21.8 \pm 0.25$ & $22.6 \pm 1.05$ & $21.6 \pm 0.00$ \\
\hline $\begin{array}{l}\text { Acacia sp. tree or shrub } \\
72.25\end{array}$ & $0.93 \pm 0.25$ & $0.90 \pm 0.30$ & $0.67 \pm 0.48$ & $0.20 \pm 0.41$ & $0.50 \pm 0.58$ & $1.00 \pm 0.00$ & $1.00 \pm 0.00$ \\
\hline $\begin{array}{l}\text { Tann } \\
70.03\end{array}$ & $24.7 \pm 1.04$ & $25.7 \pm 0.71$ & $25.5 \pm 0.69$ & $26.0 \pm 0.48$ & $25.2 \pm 0.46$ & $25.0 \pm 0.57$ & $25.6 \pm 0.00$ \\
\hline $\begin{array}{l}\text { Shrubs present } \\
58.40\end{array}$ & $0.97 \pm 0.16$ & $0.99 \pm 0.12$ & $1.00 \pm 0.00$ & $0.60 \pm 0.51$ & $0.75 \pm 0.50$ & $1.00 \pm 0.00$ & $1.00 \pm 0.00$ \\
\hline $\begin{array}{l}\text { Hummock grass present } \\
54.84\end{array}$ & $0.78 \pm 0.42$ & $0.95 \pm 0.22$ & $0.71 \pm 0.46$ & $0.33 \pm 0.49$ & $0.50 \pm 0.58$ & $1.00 \pm 0.00$ & $0.00 \pm 0.00$ \\
\hline $\begin{array}{l}\text { soild } \\
51.87\end{array}$ & $34.6 \pm 27.6$ & $20.3 \pm 16.2$ & $48.4 \pm 33.1$ & $58.2 \pm 27.3$ & $41.2 \pm 46.0$ & $31.7 \pm 19.0$ & $100 \pm 0.0$ \\
\hline $\begin{array}{l}\text { Eucalyptus camaldulensis / E. } \\
\text { victrix } 51.41\end{array}$ & $0.17 \pm 0.38$ & $0.00 \pm 0.00$ & $0.05 \pm 0.22$ & $0.00 \pm 0.00$ & $0.00 \pm 0.00$ & $0.00 \pm 0.00$ & $0.00 \pm 0.00$ \\
\hline $\begin{array}{l}\text { Tree or mallee present } \\
46.81\end{array}$ & $0.71 \pm 0.46$ & $0.44 \pm 0.50$ & $0.24 \pm 0.44$ & $0.00 \pm 0.00$ & $0.25 \pm 0.50$ & $0.75 \pm 0.50$ & $1.00 \pm 0.00$ \\
\hline $\begin{array}{l}\text { Outcrop } \\
33.09\end{array}$ & $0.80 \pm 1.35$ & $1.42 \pm 1.49$ & $0.43 \pm 1.21$ & $0.27 \pm 1.03$ & $1.00 \pm 1.41$ & $0.75 \pm 1.50$ & $0.00 \pm 0.00$ \\
\hline $\begin{array}{l}\text { Rug500 } \\
30.98\end{array}$ & $5.99 \pm 7.94$ & $7.20 \pm 9.04$ & $4.19 \pm 5.46$ & $1.67 \pm 0.91$ & $4.59 \pm 2.14$ & $10.2 \pm 14.3$ & $2.70 \pm 0.76$ \\
\hline $\begin{array}{l}\text { exMg } \\
24.37\end{array}$ & $1.65 \pm 1.39$ & $2.33 \pm 1.88$ & $2.63 \pm 2.89$ & $5.19 \pm 4.50$ & $3.48 \pm 2.23$ & $1.82 \pm 1.39$ & $14.7 \pm 7.64$ \\
\hline
\end{tabular}

1 sites occurred on average at more southerly locations, had lower annual mean temperature, and were less likely to be associated with outcrops. Further, these sites had greater soil depth and were more likely to support trees or mallees.

Similarly, Group 3 sites tended to be distributed in the southern Pilbara and have lower annual mean temperature than Group 4 sites, which had more northerly distributions. Group 3 sites were also more likely to have Acacia trees or shrubs, shrubs of any kind, or hummock grasses, but these differences were barely significant. Groups 5 and 6 had too few sites to characterise. Group 7 consisted of just two sites (PW05 and PW09), but both were very unusual for the Pilbara, in that they were riverbank sites with tall river gums and dense understorey vegetation adjacent to permanent water in Millstream-Chichester National Park.

Variation partitioning of the results of the PCNM analysis showed that, although there was a significant relationship (adjusted $R^{2}=0.12$ ) between the Bray-Curtis matrix and the environmental variables, only $7 \%$ of the observed variation could be attributed solely to environmental variables (Figure 6), while 3\% was related to spatially structured environmental variables, and $9 \%$ was purely spatial. When the analysis was restricted to include only the 83 species from species Group 1, and the 251 sites from site groups 1 and 2, the result was similar, with $7 \%$ of the observed variation attributed solely to environmental variables, $2 \%$ environmental/spatial and 9\% spatial.

PCNM generation over the 297 sites produced 168 PCNM variables, of which 59 had positive values of Moran's I, and 25 of these were significant, leading to a model with $R^{2}=0.194$. The significant PCNM variables featured patterns at similar scales to each other, and so were of limited use in explaining data structures at different scales. The models for each canonical axis are shown in Table 5. Interestingly, the distance to riparian habitat ('Dist to riparian') occurred in all four models, and the presence of trees occurred in three of the four models, highlighting the importance of trees as correlates of bird assemblage patterns in this region.

\section{Species classification}

Four major species groups were identified from the classification analysis (Figure 7). The major division in the dendrogram was between Groups 
Table 4 Differences in physical attributes between the two groups at each higher order fusion point in the dendrogram resulting from the classification of 297 sites from the Pilbara, on the basis of bird species composition, using Mann-Whitney U tests. 'Other significant attributes' are listed in order of decreasing significance. Fusions involving a group with five or less sites are omitted from the table.

\begin{tabular}{|c|c|c|c|c|}
\hline $\begin{array}{l}\text { Groups } \\
\text { separated }\end{array}$ & $\begin{array}{l}\text { Physical attribute with } \\
\text { highest significance }\end{array}$ & $\begin{array}{l}\text { Adjusted } \\
\mathrm{z} \text { value }\end{array}$ & $P$-value & $\begin{array}{l}\text { Other significant attributes, in decreasing } \\
\text { order (only attributes with significance }<0.001 \\
\text { are listed) }\end{array}$ \\
\hline $1-2$ vs. 3-7 & soilD & -5.084 & $<0.0001$ & $\begin{array}{l}\text { Rug500, Presence of Acacia trees or shrubs, } \\
\text { Latitude, Trees or mallees, Outcrop, , totK ( } P \text { for } \\
\text { Hummock grasses }=0.0011)\end{array}$ \\
\hline $3-5$ vs. $6-7$ & Trees or mallees present & -3.619 & $\begin{array}{l}\text { adjusted } P \\
=0.0054\end{array}$ & $\begin{array}{l}\text { No other variables significant after } P \text { adjusted } \\
\text { for small sample size }\end{array}$ \\
\hline 1 vs. 2 & Tann & -7.330 & $<0.0001$ & $\begin{array}{l}\text { Latitude, soilD, Outcrop, presence of trees or } \\
\text { mallees, exMg }\end{array}$ \\
\hline 3 vs. 4 & Tann & +2.840 & 0.0045 & \\
\hline
\end{tabular}

1-3 (99 species, mostly relatively widespread terrestrial species), and Group 4 (12 species associated with the coast or wetlands). The Group 4 species are all relatively infrequent in our data set because they are mostly associated with wetlands (e.g. Pacific Black Duck, Gull-billed Tern) or coastal sites (e.g. White-breasted Woodswallow, Yellow White-eye, Brahminy Kite). None of the Group 4 species occurred at more than five sites. Not surprisingly in our study area, the locations at which species in Group 4 occurred were, on average, further north than locations where species in Groups 1-3 occurred, and were sites with low topographic diversity, with low scores for vegetation except for the frequent presence of river gums (Table 6), and with relatively high levels of soil nutrients.

The next division in the dendrogram was between Group 1 and Groups 2 and 3. Most species $(n=83)$ fell into Group 1, and many of these were species that are widespread in the Pilbara and elsewhere. The most common Group 1 species were the Zebra Finch at 244 sites, Singing Honeyeater at 232, Willie Wagtail at 198, Black-faced Woodswallow at 188, Diamond Dove at 167, Budgerigar at 156, Black-faced Cuckoo-shrike at 155, Yellow-throated Miner at 154, Painted Finch at 152 and Pied Butcherbird at 150. In our study area, Group 2 and 3 species were more likely to occur at southern sites with trees and shrubs rather than hummock grasses, and with lower annual mean temperatures and generally lower soil nutrients. Group 2 comprised three species (Black-breasted Buzzard, Black Kite and Pheasant Coucal) that are relatively uncommon in the Pilbara and each occurred at only two sites, so are not considered further. Group 3 comprised 13 species whose distributions are primarily in the southern arid zone, and within the Pilbara are largely restricted to the Hamersley subregion (e.g. the Redthroat, which occurred at 12 sites, and Chestnut- backed Quail-thrush, at 11 sites, and Yellow-rumped Thornbill and Chiming Wedgebill, each at seven sites) or at wetter sites such as at Millstream (e.g. Grey Fantail).

Group 1 could be further subdivided. Sub-group 1a included 62 species, while there were 21 species in sub-group $1 \mathrm{~b}$. Compared with $1 \mathrm{a}$ species, $1 \mathrm{~b}$ species were associated with sites that were more likely to have E. camaldulensis or E. victrix present, had deeper soils in lower rainfall areas, but were closer to streamlines or major riparian zones (Table 6). The species in sub-group $1 \mathrm{~b}$ are ones that, in other parts of the arid zone, are more likely to be associated with wooded areas than most of those in sub-group 1a. These species are mostly widespread in the arid zone, but most likely encountered along drainage lines, especially those with eucalyptse.g. Little Corella, Peaceful Dove, White-plumed Honeyeater, Bush Stone-Curlew and Black-tailed Treecreeper.

Sub-group 1a could be sub-divided still further: (i) 14 species, primarily birds of plains or subdued topography vegetated by low grasslands or low shrubs, e.g. Australian Pipit, Brown Songlark and Little Button-quail; (ii) 26 species that are common and widespread, such as the Zebra Finch, Willie Wagtail, Singing Honeyeater, Diamond Dove, Blackfaced Woodswallow, Grey-headed Honeyeater, Spinifex Pigeon and Crested Pigeon, and which inhabit a range of relatively open habitats; and (iii) 22 species that were similar, but less likely to occur in northern or more arid habitats (Chestnutrumped Thornbill, Slaty-backed Thornbill and White-browed Babbler do not occur in the northern Pilbara, while the Hooded Robin and Red-capped Robin occur more frequently in the southern Pilbara than in the north; in the Pilbara all these species are often associated with mulga), and some that are more likely to occur where eucalypts are present, e.g. Australian Ringneck and Weebill. 
Dissimilarity

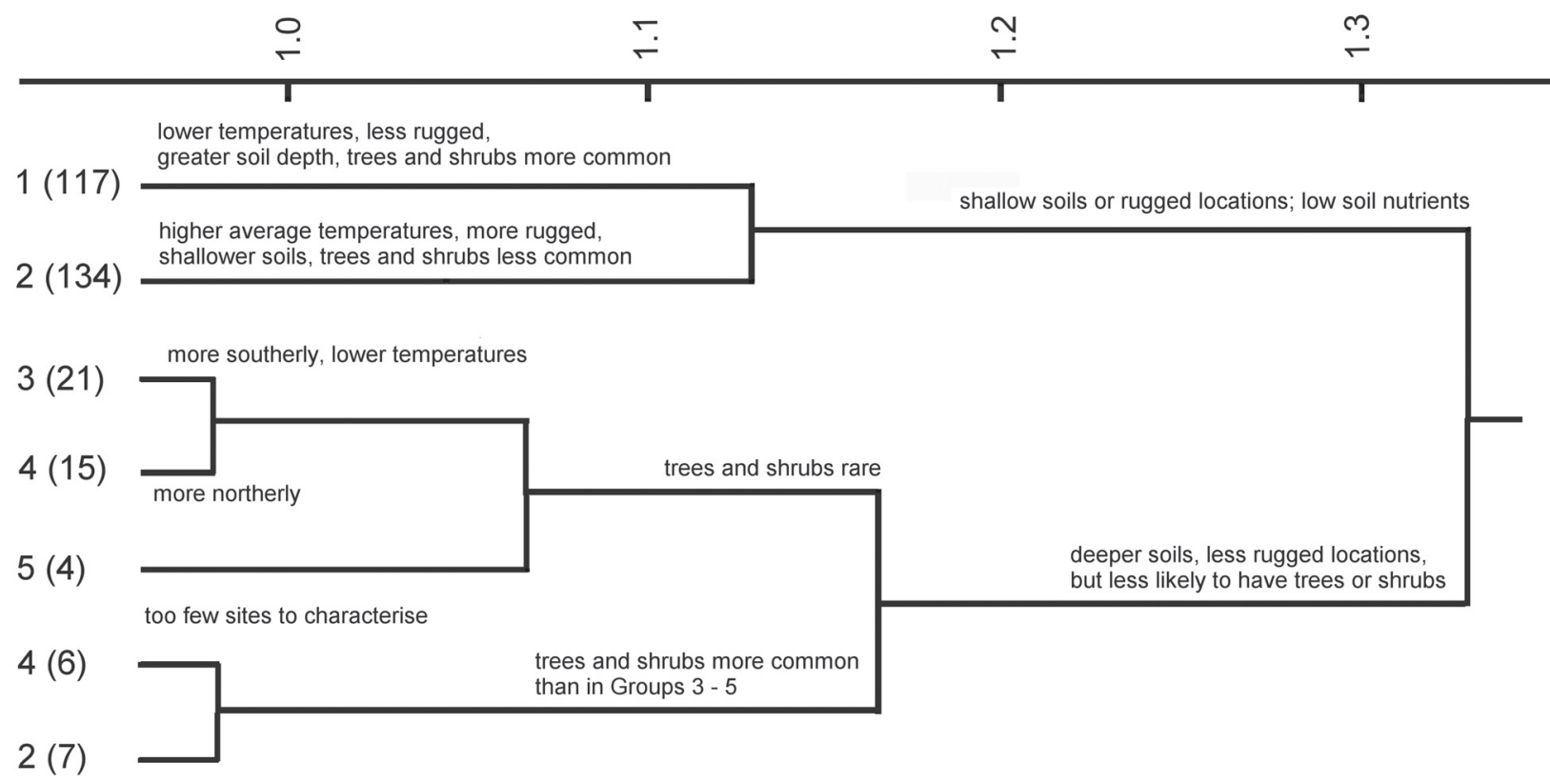

Figure 4 Seven group site classification of the 297 sites surveyed for diurnal birds in the Pilbara region. Sites were classified on the basis of bird species presence/absence at each site. Numbers to the left of the figure are group numbers (see text); numbers in brackets are the number of sites in each group.

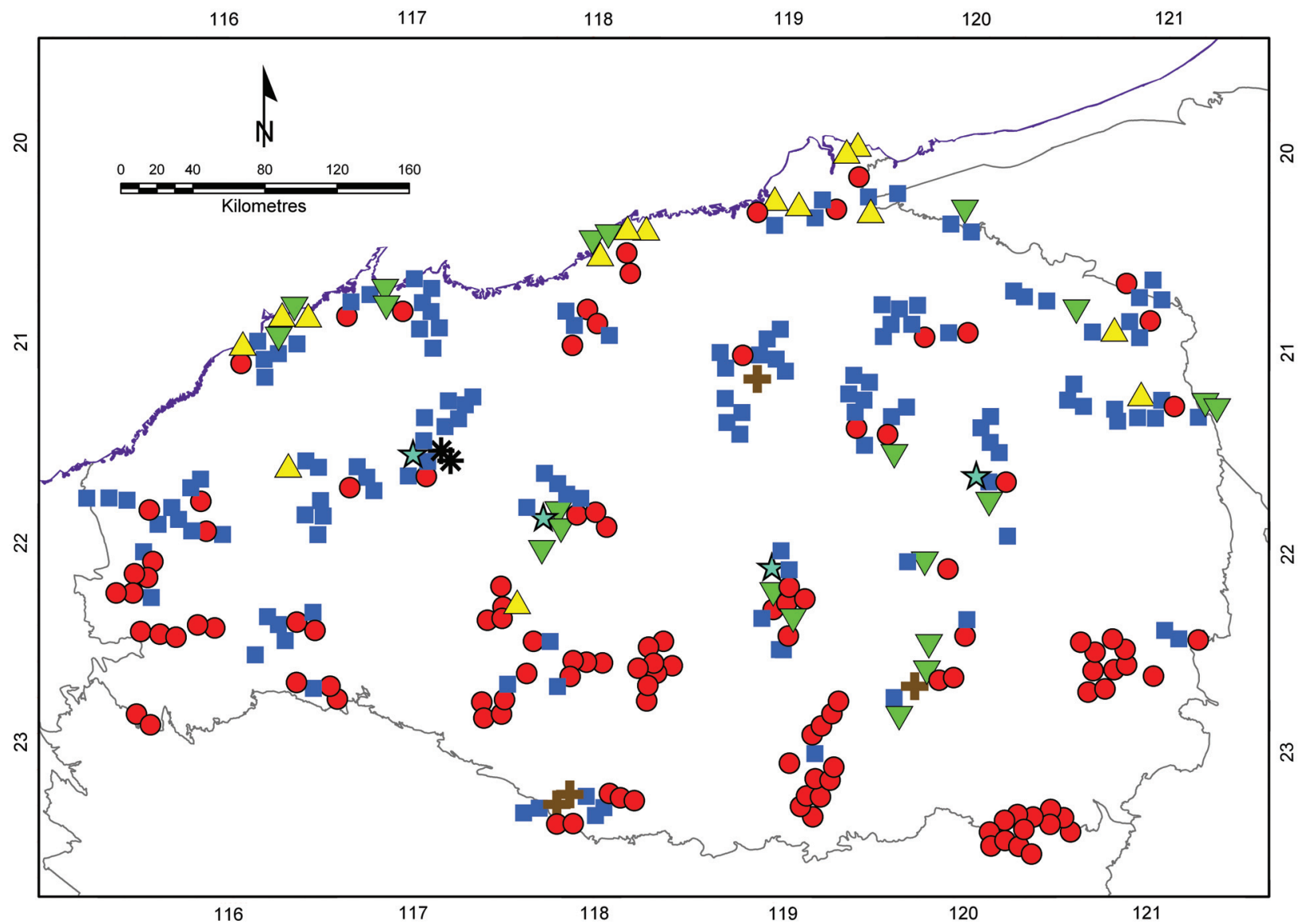

Figure 5 Distribution of the seven-group partitions in the classification of 297 sites in the Pilbara region, based on bird species presence $/$ absence. Red circle $=$ Group 1, dark blue square $=$ Group 2, inverted green triangle $=$ Group 3 , yellow triangle $=$ Group 4, light blue star $=$ Group 5, brown cross $=$ Group 6, solid black asterisk $=$ Group 7 . 
Table 5 Multiple regression models derived for each of the four significant canonical axes from the PCNM analysis of bird occurrence at the 297 sites sampled in the Pilbara. First line: adjusted $R^{2}$ of the regression of the model on a subset of backward selected environmental variables. Second line: $P$-values for these models. Other lines: $P$-values of the regression coefficients for the environmental variables in the model being considered.

\begin{tabular}{|c|c|c|c|c|}
\hline Canonical axis & 1 & 2 & 3 & 4 \\
\hline Adjusted $\mathrm{R}^{2}$ & 0.067 & 0.232 & 0.118 & 0.258 \\
\hline$P$-value of model & $<0.0001$ & $<0.0001$ & $<0.0001$ & $<0.0001$ \\
\hline Tann & & & & $<0.0001$ \\
\hline PcoQ & & 0.0194 & & \\
\hline Rug500 & & 0.0001 & & \\
\hline Asp & & & 0.0056 & \\
\hline Riv & & & & $<0.0001$ \\
\hline Gcov & & & & $<0.0001$ \\
\hline Dist to riparian & 0.0360 & 0.0024 & 0.0007 & 0.0057 \\
\hline Sand & & & & 0.0050 \\
\hline $\mathrm{pH}$ & 0.1075 & & & \\
\hline totP & & 0.0271 & 0.1609 & 0.0907 \\
\hline exCa & & $<0.0001$ & & \\
\hline exMg & 0.0030 & & & \\
\hline exK & & & 0.0002 & 0.0700 \\
\hline Trees or mallees present & & 0.0641 & & \\
\hline $\begin{array}{l}\text { Eucalyptus camaldulensis and/or E. victrix } \\
\text { present }\end{array}$ & 0.0117 & & 0.0190 & \\
\hline Acacia sp. trees or shrubs present & & 0.0053 & & \\
\hline Hummock grass present & & 0.1481 & & 0.0100 \\
\hline
\end{tabular}

Table 6 Differences in physical attributes between the two groups at each higher order fusion point in the dendrogram resulting from the classification of 111 bird species from the Pilbara, on the basis of occurrence at 297 sites, using Mann-Whitney U tests. 'Other significant attributes' are listed in order of decreasing significance. Fusions involving a group with five or less sites are omitted from the table.

\begin{tabular}{|c|c|c|c|c|}
\hline $\begin{array}{l}\text { Groups } \\
\text { separated }\end{array}$ & $\begin{array}{l}\text { Physical attribute } \\
\text { with highest } \\
\text { significance }\end{array}$ & $\mathrm{z}$ value & $P$-value & $\begin{array}{l}\text { Other significant attributes, in order of } \\
\text { increasing } P \text {-value } \\
\text { (only attributes with significance }<0.001 \text { are } \\
\text { listed) }\end{array}$ \\
\hline $1-3$ vs. 4 & Acacia sp. present & 5.641 & $<0.0001$ & $\begin{array}{l}\text { Latitude, Rug500, Tann, Trees or mallees present, } \\
\text { Outcrop, Hummock grass present, Eucalyptus. } \\
\text { camaldulensis or E. victrix, exMg }\end{array}$ \\
\hline 1 vs. $2-3$ & Acacia sp. present & 5.579 & $<0.0001$ & $\begin{array}{l}\text { Trees or mallees present, Hummock grass } \\
\text { present, E. camaldulensis or E. victrix, Latitude, } \\
\text { totK, exMg, Tann, totP, EC }\end{array}$ \\
\hline 1a vs. $1 b$ & $\begin{array}{l}\text { E. camaldulensis } \\
\text { or E. victrix }\end{array}$ & -5.735 & $<0.0001$ & $\begin{array}{l}\text { soilD, Shrubs present, Latitude, PcoQ, pH, Riv, } \\
\text { Tann, Long, Distance to riparian, Acacia sp. } \\
\text { present }\end{array}$ \\
\hline $\begin{array}{l}\text { 1a (i-ii) vs. } \\
\text { 1a (iii) }\end{array}$ & Tann & 6.150 & $<0.0001$ & $\begin{array}{l}\text { Latitude, Trees or mallees present, totP, Acacia } \\
\text { spp. present, totK, Gcov, pH, Distance to riparian, } \\
\text { exK, Sand }\end{array}$ \\
\hline 1a (i) vs. 1a (ii) & Tree or mallee present & -5.076 & $<0.0001$ & totP, Outcrop, Rug500, Riv, soilD \\
\hline
\end{tabular}




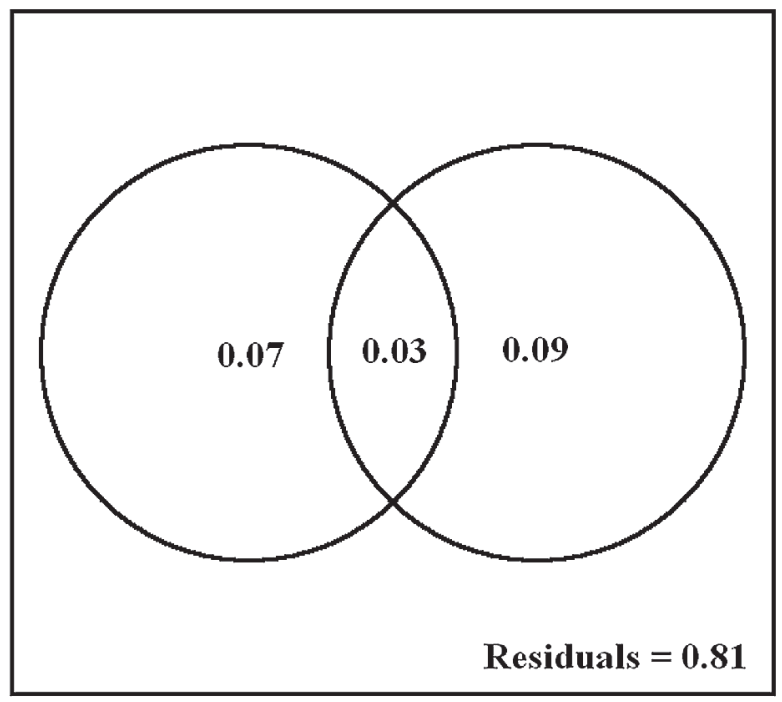

Figure 6 Variation partitioning of results from a PCNM analysis of the full data set of bird composition data from 297 sites in the Pilbara region and 25 uncorrelated environmental variables. Only $7 \%$ of the variation was attributed solely to environmental variables and $3 \%$ to spatially structured variables, while $9 \%$ of the observed variation is purely spatial.

Compared with species of 1a (i-ii), the species of 1a (iii) occurred at sites that were on average cooler (and further south), more likely to have shrubs or trees and a higher amount of ground cover, had finer-textured soils with higher levels of some nutrients, and tended to be closer to riparian zones. Compared with species of 1a (i), those of $1 \mathrm{a}$ (ii) occurred at sites that were more likely to have trees or mallees, were associated with rugged topography and outcrops, had shallow soils and were distant from rivers (Table 6).

\section{DISCUSSION}

\section{Limitations of sampling and data}

Many bird assemblages do not appear to be highly structured and temporally stable. Changes in species composition and abundances have been observed during numerous long-term studies (Wiens 1989; MacNally 1996; Collins 2001; Holmes and Sherry 2001). Any short-term sampling of bird communities is thus likely to provide just a 'snapshot' in time and not fully reflect their dynamic nature or long-term trends. In order to address these constraints, we set up a sampling regime to minimise the possible impacts of shortterm sampling. We sampled for birds at each site during two field trips, several months apart. Each site was visited on multiple occasions during a field trip and at different times of the day to maximise the chances of encountering a large proportion of the bird species resident or using the site. In addition, a different observer undertook the sampling at each site on each field trip. Such a sampling regime appears to be suitable to compile assemblage data for birds at each site, but there are inevitably limitations on its effectiveness.

Sampling was not undertaken during the summer months when diurnal temperatures in the Pilbara often exceed $40^{\circ} \mathrm{C}$. Some seasonal migratory birds might be missed as a consequence, but the number is likely to be small in terrestrial habitats (e.g. cuckoos, kingfishers) compared to coastal wetlands with their high proportion of migratory waders. There is considerable nomadism
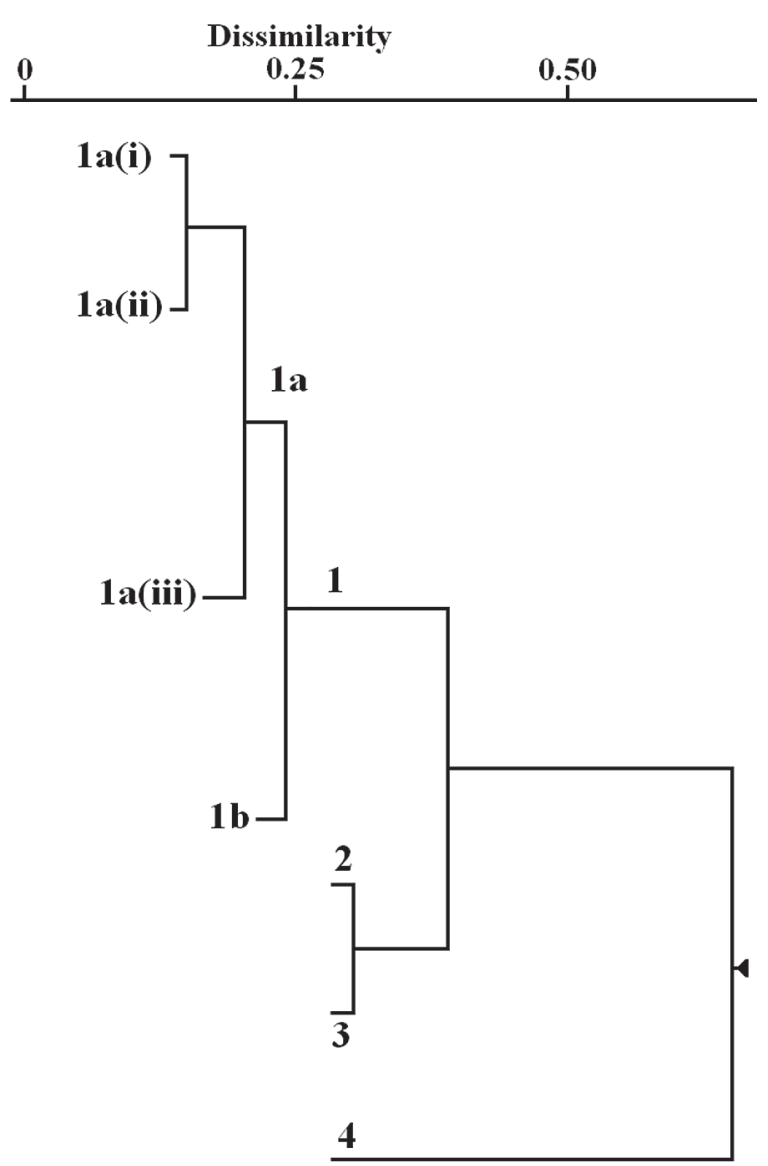

Figure 7 Classification of 111 diurnal bird species according to their occurrence at 297 terrestrial survey sites in the Pilbara. Group 1 species $(n=83)$ are widespread in the Pilbara and elsewhere, Group 2 species (3) are rare in the Pilbara, Group 3 species (13) have primarily southern distributions or occur at moist sites, while Group 4 species (12) inhabit wetlands or coasts. Group 1a (i) species (14) are primarily inhabitants of plains with low grasslands, Group 1a (ii) (26) are common and widespread species, Group 1a (iii) (22) have more southerly distributions and inhabit areas with shrubs or trees, and Group $1 \mathrm{~b}$ species (21) are more likely to be associated with wooded areas than Group 1a species. 
in the region due to the irregularity of the climate, especially with anatids, Straw-necked Ibis, Black-tailed Native Hen, quails, Crimson Chat, White-winged Triller and Masked Woodswallow (R.E. Johnstone, A.H. Burbidge and J.C. Darnell, unpublished data). The extent and intensity of rainfall in the months and weeks prior to sampling may therefore strongly influence bird assemblages. For instance, after good rains, nomadic species such as Black and Pied Honeyeaters may be abundant in some habitats and, conversely, dry periods and droughts are likely to reduce the diversity of bird species at a site. An exception would be riparian and wetland sites, where assemblages may prove to be more diverse in drought as bird species seek refuge from drier habitats (Kingston 2005).

While nocturnal species were not included in the data analysis, such species (owls, nightjars) are relatively small in number in the Pilbara and are unlikely to affect the overall nature of the observed assemblages significantly. Most species (e.g. Boobook Owl, Australian Owlet-nightjar, Spotted Nightjar) were observed to be fairly ubiquitous across the Pilbara.

The survey concentrated on the most widespread terrestrial habitats of the Pilbara, so areas of wetlands, coastal mud flats and mangal were not included in sampled sites. Such areas have their own characteristic bird assemblages (R.E. Johnstone, A.H. Burbidge and J.C. Darnell, unpublished data), so any consideration of the adequacy of conservation of representative habitats must account for this absence in the survey data set.

For conservation management, it is also important to know where rare, threatened or cryptic bird species occur. While some such species were encountered occasionally during the survey, their low densities and/or restricted distributions resulted in the collection of insufficient data to be able to model their habitat requirements. Observers in this survey deliberately targeted the array of microhabitats present at each site, with the aim of finding all species using the site, but to survey for cryptic and threatened species adequately across their range, much greater sampling effort would be required if using our sampling design. Alternatively, specific surveys using other techniques (such as call playback and remote cameras) and targeting known habitats would be more efficient for determining the distribution and habitat requirements of these species.

Nevertheless, despite these caveats, we believe that the survey design was appropriate and adequate to draw conclusions concerning patterns of bird distribution at a regional scale.

\section{Patterns observed}

Patterns of bird species assemblage composition in the Pilbara are broadly correlated with a range of vegetation and topographic variables, but climatic variables did not appear strongly as correlates in our data. This is in contrast to some other studies in the arid zone (e.g. Burbidge et al. 2000), where climatic variables were important correlates of broad scale patterns, while substrate and vegetation were more important at local scales, although similar to some other studies (Pavey and Nano 2009).

While assemblage composition is significantly correlated with environmental variables, the measured variables explain only a fraction of the observed patterning. There could be various reasons for this. It may be that our sampling was inadequate, as sampling over such a large portion of the Australian arid zone, with its inherent variability in seasonal conditions, is challenging. Our sampling may have been weak at some individual sites, but the regional species accumulation curve suggested that our sampling was adequate to detect regional scale trends. It could be that we did not use the most appropriate environmental variables, or that the ones we used were not at an appropriate scale. However, the variables we did use were equivalent to, or similar to, variables that have been used successfully to explain assemblage composition or distributional patterns in other studies (Wiens 1989; Burbidge et al. 2000; Pavey and Nano 2009).

Assuming that we did record appropriate environmental variables, interpretation of relationships between these variables and bird assemblage composition would be difficult where nomadism is high, and it is known that nomadism is a feature of the Australian desert bird fauna (Davies 1984). A high incidence of nomadism might blur relationships with environmental variables, at least at the scale at which we were sampling (Allen and Saunders 2002).

Another possible explanation is that the Pilbara is relatively uniform from the perspective of terrestrial birds - climatic gradients are not steep, and most of the Pilbara is rocky, and covered with Triodia hummock grasses. In some other desert areas (Rodríguez-Ferraro and Blake 2008) the most abundant bird species are widespread generalists, and this appears also to be the case in the Pilbara. As in many other parts of the world (Wiens 1989), foliage height diversity (in the form of shrubs and trees) does influence bird species diversity and assemblage composition. In the Pilbara, this is particularly noticeable along the major streamlines, where bird species richness is much higher where there is well-developed riparian vegetation in the form of tall Eucalyptus and/or Melaleuca trees. However, major riparian zones occur across the Pilbara and, with the obvious exceptions of temperature and precipitation variables, most of the 
environmental variables that we measured are also relatively uniform at a regional scale - i.e. having only weak or irregular regional gradients. This is consistent with the situation further south in the Carnarvon Basin where no sharp biogeographic boundaries are evident in bird species distributions in non-coastal areas (Burbidge et al. 2000).

Our classification analysis of Pilbara bird species resulted in a broad sub-division of the bird fauna into relatively ubiquitous species with subdivisions based on broad vegetation parameters, plus southern components and coastal/wetlands components. Elsewhere in Australia (Pavey and Nano 2009) and the world (Blendinger 2005), habitat heterogeneity and structural complexity of vegetation are important correlates of avian assemblage structure in desert environments. More complex vegetation in arid areas tends to occur in areas where water availability is higher (Morton 1990) and this suggests that bird assemblage composition may ultimately be driven by moisture availability. For instance, Fisher et al. (1972) observed that honeyeaters in an arid zone are surprisingly dependent on water. Main (1976), in a discussion of adaptations of Australian vertebrates to desert conditions, suggested that most honeyeaters frequent 'late and climax stages' where the vegetation is at its maximum diversity with numerous sources of nectar and insects. Paltridge and Southgate (2001) and Burbidge and Fuller (2007) have demonstrated significant relationships between bird abundance and rainfall in other Australian deserts, and James et al. (1995) have highlighted how the availability of water and nutrients are dominant influences in the distribution and abundance of terrestrial biota in arid landscapes. Although our results did not indicate a strong relationship with rainfall, our analyses of both species richness and composition did show relationships with the presence of trees and riparian zones, suggesting that biologically significant relationships with water availability may extend well beyond the honeyeaters.

\section{Birds of Triodia grasslands}

Much of the Pilbara is covered with spinifex (Triodia spp.), usually with scattered shrubs or small trees, often species of Acacia. A core set of species - Black-faced Woodswallow (aerial insectivore), Singing Honeyeater (arboreal insectivore), Zebra Finch (small seed eater), Willie Wagtail (aerial/ gleaning insectivore) and Diamond Dove (medium seed eater) - are almost ubiquitous throughout the Pilbara, and are the characteristic species of Group 1 in our species analysis. The Torresian Crow (omnivore) and Brown Falcon (generalist carnivore) also occur frequently. These are all common, widespread species, both within and beyond our study area, and none of these species is confined to Triodia; they are essentially species of open, mostly arid to semi-arid habitats with scattered shrubs or trees. Bird assemblage structure in Triodia grasslands seems not to be well studied, but it may be that these assemblages are less stable than those in more heavily vegetated arid zone habitats (Reid et al. 1993). Nevertheless, the assemblages we observed were generally similar to those reported in the Tanami Desert (Paltridge and Southgate 2001), one obvious difference being that Malurus species (predominantly leaf-gleaning insectivores) were much more commonly encountered in the Tanami.

While we did not record abundances, it was obvious that abundances varied considerably. For example, during most of our sampling, Spinifex Pigeons were widespread, usually occurring in pairs and sometimes recorded nesting, but under very dry conditions were noted to be in wandering flocks. This is consistent with previous observations in the Pilbara (How et al. 1991), where drought led to increased flock size, or the movement of granivores out of drought-affected areas. Increase in flock size and nomadism suggests that seed supply is a limiting factor in relation to granivorous birds in these assemblages, as it appears to be in South American deserts (Blendinger and Ojeda 2001).

\section{Other grasslands}

While hummock grasses are widespread in the Pilbara, other grasslands also occur. Twelve of our sites were dominated by bunch grasses or tussock grasses, including Eragrostis spp., Chrysopogon spp., Paspalidium spp. and Aristida spp. These sites were characterised by relatively small ground-dwelling omnivores or granivores from Group 1a(i) of our species classification - Horsfield's Bushlark (at 92\% of sites), Little Button-quail (58\%) and Australian Pipit (50\% of sites). Zebra Finches occurred at those sites $(42 \%)$ where shrubs were nearby or scattered through the site, and various other insectivores or omnivores also occurred at sites with shrubs.

\section{Birds of mulga woodlands}

A number of our sites supported some form of mulga (see Miller et al. [2002] for a description of the variation in 'mulga'), but 15 sites supported good stands of trees normally described as 'mulga'. The most commonly encountered species in these sites were from Groups 1a (ii) and (iii) of our species classification-the Singing Honeyeater (at $93 \%$ of sites), Rufous Whistler (87\%), Zebra Finch $(87 \%)$, Pied Butcherbird (80\%), Willie Wagtail $(80 \%)$ and Crested Bellbird $(80 \%)$. At our mulga sites, we recorded all the frequently occurring or 'core' species listed by Cody (1994) and Recher and Davis (1997) except the Southern Whiteface, 
which does not occur in the Pilbara. Some species, such as the Red-capped Robin and Slaty-backed Thornbill, were recorded less frequently in our study, and some, including the Pied Butcherbird, were recorded much more frequently by us. Nevertheless, the general structure of the bird community observed in mulga sites in the Pilbara was similar to that found elsewhere (Johnstone 1983; Cody 1994; Recher and Davis 1997; Burbidge et al. 2000; Leavesley 2008), but with local variation, probably depending on the available species pool in the area, variation in mulga stands and their position in the landscape (Burbidge et al. 2000).

It is also worth noting that some bird taxa in the Pilbara are restricted largely to mulga (R.E. Johnstone, A.H. Burbidge and J.C. Darnell, unpublished data): the desert subspecies of the Western Gerygone (Desert Gerygone, Gerygone fusca mungi) favours tall mulga scrub and woodlands, the Slaty-backed Thornbill forages in the canopy of tall mulga, the Grey Honeyeater prefers thickets of mulga and other acacias, the Hooded Robin favours open mulga and the inland subspecies of the Grey Fantail (White-tailed Fantail, Rhipidura fuliginosa albicauda) favours dense mulga with emergent eucalypts, while the Grey-crowned Babbler occurs primarily in mulga or riparian areas. In the current survey, all records of Chestnut-rumped and Broadtailed Thornbills, and almost all records of Spinycheeked Honeyeaters, were at mulga sites.

\section{Birds of riparian sites}

Riparian sites in the Pilbara are species rich (Figure 3), as are riparian sites in other arid areas (e.g. James et al. 1995; Kingston et al. 2002). Presumably this is because they provide a broad array of feeding substrates (such as eucalypt tree trunks and large branches for foraging by the Black-tailed Treecreeper) and nesting sites (e.g. tree hollows for nesting by parrots) that are in short supply in other Pilbara habitats. Some of these sites also provide drinking water for birds from surrounding habitats (e.g. Spinifex Pigeon and Painted Finch) and hence riparian sites may exert a fundamental influence on the avian assemblages of neighbouring areas (Kingston 2005). The provision of artificial water sources for pastoralism and the riparian vegetation that develops around some of these facilities may also lead to increased local bird species richness. In a study comparing pastoral dams and natural water bodies in north-western New South Wales, Schneider and Greisser (2009) found that both these types of riparian habitats supported bird assemblages with higher species richness than surrounding habitats, particularly in relation to sedentary species.

The characteristic species of riparian sites in the Pilbara are those of Group $1 \mathrm{~b}$ from our species analysis, including Peaceful Dove, Little Corella, Blue-winged Kookaburra, Black-tailed Treecreeper and White-plumed Honeyeater. However, as found elsewhere in the Australian arid zone (Kingston 2005), many of the species common in riparian sites were also common in nearby upslope sites. Within the Pilbara, some species are restricted to riparian habitats; for example the Barking Owl (not included in our analysis) occurs only where there are both large river gums and paperbarks (Storr 1984; R.E. Johnstone, A.H. Burbidge and J.C. Darnell, unpublished data). The riverine assemblage that we identified is similar to that identified by Pavey and Nano (2009) in central Australia. They identified 'diagnostic species' in their riverine and floodplain sites, and these species were similar in characteristics to our Group $1 \mathrm{~b}$ species. They were mostly non-passerines, including six cavity-nesting parrots and cockatoos, or large omnivorous passerines including Pied Butcherbird and Magpielark, but also included aggressive honeyeaters (Yellow-throated Miner and Whiteplumed Honeyeater).

\section{Implications for conservation}

The low level of variation in occurrence of terrestrial bird species explained by environmental variables suggests that the existing large conservation reserves, in the western, central, southern and eastern parts of the study area, are likely to contain the bulk of the variation expected in terrestrial bird communities across the rocky landscapes of the Pilbara. Inspection of Figures 1 and 5 and the two-way table of site by species occurrences shows that this is the case. However, this study also shows that it is important that substantial areas of major riparian vegetation be retained and carefully managed, and that important examples be included in the conservation reserve system. Fortunately, excellent areas of such habitats are contained in Millstream-Chichester National Park, and there are also areas in Karijini National Park and Meentheena Conservation Park. However, there are other extensive riparian habitats, notably in the Weeli Wolli catchment north-west of Newman, and on the De GreyOakover River system in the north-east Pilbara, that are not included in conservation reserves and require better protection than currently exist.

Coastal habitats are also poorly represented or absent from the conservation reserve system; in particular, blocks of mangal, grasslands of bunch and tussock grasses on the Roebourne Plain, and the marshes and flood-outs of major rivers such as between Port Hedland and Pardoo, and the lower Fortescue. Extensive stands of mulga sites are restricted in the conservation estate. There are some good stands of mulga in the southern 
Pilbara, such as in Karijini National Park and the Ophthalmia Range but, given the variability in mulga woodlands and their fauna and the impacts of current grazing and fire regimes, these bird assemblages are unlikely to be conserved adequately at present.

\section{Threats to Pilbara birds}

Threats to Pilbara bird communities are increasing, and include impacts of grazing by introduced herbivores, altered and inappropriate fire regimes, shrubby weeds, introduced grasses and, in some places, mining infrastructure (Freudenberger et al. 1997; McKenzie et al. 2009). The number of development projects in the Pilbara is increasing, and some mining infrastructure projects could have hydrological impacts, particularly on riparian sites such as along Weeli Wolli Creek. However, most of the negative impacts on terrestrial birds in the immediate future are likely to result from direct or indirect impacts from introduced herbivores and their management, particularly the injudicious use of fire. Cattle impact directly on some bird habitats through trampling and grazing; for example, the vegetation on some coastal limestone ridges is almost completely removed, with the consequent loss of most of the original bird fauna in these habitats. Grazing, particularly on the coastal plains, results in a dense monoculture of some Acacia species, which are depauperate in birds, and lead to exclusion of the grassland bird fauna.

Pre-European fire regimes in the Pilbara presumably consisted largely of Aboriginal firing with burns that were small in area, similar to what occurred in nearby desert areas (Burrows et al. 2006). Today, fires in the Pilbara are frequent and extensive (McKenzie et al. 2009) leaving few unburnt refugia. In combination with the direct impacts of grazing, these fires limit the regeneration of fire-susceptible species such as mulga and lead to an absence of large, mature Triodia in many areas (Start 1986; van Etten 1998; May and McKenzie 2003). Opportunistic observations in such areas indicate that they are unsuitable even for some relatively common, widespread species, such as the Spinifexbird, as well as less common Triodia specialists like Striated Grasswren and Rufous-crowned Emuwren. Frequent fire also encourages the spread of the introduced Buffel Grass (Cenchrus ciliaris) (Butler and Fairfax 2008), which is common in the Pilbara, particularly in riparian areas (McKenzie et al. 2009). The impact on birds is unknown but, given the interactions between fire, grazing and Buffel Grass, impacts are likely to be significant (Smyth et al. 2009). The increase in density of Buffel Grass may have resulted in positive outcomes for some bird species, such as the Stubble Quail and Brown Quail, but, judging from experience elsewhere (Flanders et al. 2006), it is likely to be having a negative impact for most species.

The possible impacts of climate change on Pilbara birds are poorly known, but it is possible that increasing cyclonic events (McKenzie et al. 2009) could result in episodes of high bird mortality, while changes in rainfall could alter the distribution and extent of some vegetation communities and, in turn, their bird assemblages. Forecast increases in temperature, rainfall variability and droughts in the Pilbara (CSIRO and Bureau of Meteorology 2007; Dunlop and Brown 2008) may also influence fire regimes and result in larger summer wildfires with concomitant threats to fire-sensitive plant communities and their avifauna, especially mulga and riparian woodlands.

\section{ACKNOWLEDGEMENTS}

Major funding for this project was provided by the WA Department of Environment and Conservation, with contributions from the Western Australian Museum, the Commonwealth Government (through the Natural Heritage Trust, NHT2) and Straits Resources. Substantial in-kind support was also provided by Rio Tinto Iron Ore, BHP Billiton Iron Ore and Kitchener Mining (Bamboo Creek Operation).

We gratefully acknowledge the numerous Pilbara pastoralists and Aboriginal communities for permission to access their leases and/or land. We would like to thank the managers of the following pastoral stations for access to areas under their management: Bonney Downs, Coolawanyah, Corunna Downs, Glen Florrie, Hillside, Karratha, Mallina, Marillana, Mardie, Mount Florance, Mount Stuart, Mount Welcome, Mulga Downs, Munda, Mundabullangana, Nanutarra, Roy Hill, Sherlock, Uaroo, Warrawagine and Wyloo. In particular, Robyn and Tony Richardson of Mt Florance Station provided free access to their camping ground for the survey site installation and sampling teams, and Rio Tinto Iron Ore provided access to subsidised housing for the first installation team while operating out of Karratha.

DEC Pilbara Region and National Park staff at Karratha, and at Karijini and MillstreamChichester National Parks, provided subsidised accommodation for site installation and sampling teams, and the Department of Water provided access to Tabletop Hill, Harding Dam and sites along the West Pilbara water supply pipeline. Rio Tinto Iron Ore and BHP Billiton Iron Ore are acknowledged for permission to enter their exploration leases and for granting access to their rail access roads.

Jim Rolfe assisted with data preparation, and 
Matthew Williams assisted with statistical analyses. Claire Stevenson, Phil Stone, Neil Hamilton, Laurie Smith, Bill Rutherford and Rob Davis each played a major role in assisting to collect the field data. Tom Smith and Kate George also assisted with bird sampling and logistic support. Stephen van Leeuwen provided some of the GIS layers used in Figure 1 and Norm McKenzie provided helpful comments on a draft manuscript.

\section{REFERENCES}

Alldredge, M.W., Simons, T.R. and Pollock, K.H. (2007). Factors affecting aural detections of songbirds. Ecological Applications 17: 948-955.

Allen, C.R. and Saunders, D.A. (2002). Variability between scales: predictors of nomadism in birds of an Australian Mediterranean-climate ecosystem. Ecosystems 5: 348-359.

Austin, M.P. and Belbin, L. (1982). A new approach to the species classification problem in floristic analysis. Australian Journal of Ecology 7: 75-89.

Barrett, G., Silcocks, A., Barry, S., Cunningham, R. and Poulter, R. (2003). The new atlas of Australian birds. Royal Australasian Ornithologists Union: Hawthorn East, Australia.

Beard, J.S. (1975). Vegetation survey of Western Australia: 1:1 000000 vegetation series: explanatory notes to Sheet 5: the vegetation of the Pilbara area. University of Western Australia Press: Nedlands, Australia.

Belbin, L. (1980). TWOSTEP: a program incorporating asymmetric comparisons that uses two steps to produce a dissimilarity matrix. Technical Memorandum 80/9, CSIRO Division of Water and Land Resources: Canberra, Australia.

Belbin, L. (1989). Technical reference, PATN pattern analysis package. CSIRO Division of Wildlife and Ecology: Canberra, Australia.

Belbin, L. (1991a). The analysis of pattern in biosurvey data (pp. 176-190). In: Margules, C.R. and Austin, M.P. (eds), Nature conservation: cost effective biological surveys and data analysis. CSIRO: Melbourne, Australia.

Belbin, L. (1991b). Semi-strong hybrid scaling, a new ordination algorithm. Journal of Vegetation Science 2: 491-496.

Blakers, M., Davies, S.J.J.F. and Reilly, P.N. (1984). The atlas of Australian birds. Melbourne University Press: Melbourne, Australia.

Blendinger, P.G. (2005). Foraging behaviour of birds in an arid sand-dune scrubland in Argentina. Етu 105: 67-79.

Blendinger, P.G. and Ojeda, R.A. (2001). Seed supply as a limiting factor for granivorous bird assemblages in the Monte Desert, Argentina. Austral Ecology 26: 413-422.

Borcard, D., Legendre, P., Avois-Jacquet, C. and Tuomisto, H. (2004). Dissecting the spatial structure of ecological data at multiple scales. Ecology 85: 1826-1832.

Borcard, D., Legendre, P. and Drapeau, S. (1992). Partialling out the spatial component of ecological variation. Ecology 73: 1045-1055.
Burbidge, A.A., Casperson, K.D. and Fuller, P.J. (1987). Birds (pp. 153-178). In: McKenzie, N.L. and Robinson, A.C. (eds), A biological survey of the Nullarbor Region South and Western Australia in 1984. South Australian Dept of Environment and Planning, Adelaide, Western Australian Department of Conservation and Land Management: Perth, and South Australian National Parks and Wildlife Service: Adelaide, Australia.

Burbidge, A.A. and Fuller, P.J. (2007). Gibson Desert birds: responses to drought and plenty. Еmu 107: 126-134.

Burbidge, A.A., Fuller, P.J. and McKenzie, N.L. (1995). Vertebrate fauna. Records of the Western Australian Museum, Supplement 49: 208-245.

Burbidge, A.H., Johnstone, R.E., Fuller, P.J. and Stone, P. (2000). Terrestrial birds of the southern Carnarvon Basin, Western Australia: contemporary patterns of occurrence. Records of the Western Australian Museum, Supplement 61: 449-464.

Burbidge, A.H., McKenzie, N., van Leeuwen, S., Gibson, L., Doughty, P., Guthrie, N., Durrant, B. and Pearson, D. (2006). Between rock and a hard place: rich biological patterns amongst ancient red rocks. Landscope 21 (3): 12-19.

Burrows, N.D., Burbidge, A.A., Fuller, P.J. and Behn, G. (2006). Evidence of altered fire regimes in the Western Desert region of Australia. Conservation Science Western Australia 5: 14-26.

Butler, D.W. and Fairfax, R.J. (2008). Buffel Grass and fire in a Gidgee and Brigalow woodland: a case study from central Queensland Ecological Management and Restoration 4: 120-125.

Byrne, M., Yeates, D.K., Joseph, L., Kearney, M., Bowler, J., Williams, M.A.J., Cooper, S., Donnellan, S.C., Keogh, J.S., Leys, R., Melville, J., Murphy, D.J., Porch, N., Wyrwoll, K.-H. (2008). Birth of a biome: insights into the assembly and maintenance of the arid zone biota. Molecular Ecology 17: 4398-4417.

Caughley, G. and Gunn, A. (1996). Conservation biology in theory and practice. Blackwell Science: Cambridge, U.S.A.

Clarke, K.R. and Gorley, R.N. (2006). PRIMER v6: user manual/tutorial. PRIMER-E Ltd: Plymouth, U.K.

Cody, M.L. (1994). Mulga bird communities, 1, species composition and predictability across Australia. Australian Journal of Ecology 19: 206-219.

Collins, S.L. (2001). Long-term research and the dynamics of bird populations and communities. Auk 118: 583-588.

Colwell, R.K. (2006). EstimateS. Statistical estimation of species richness and shared species from samples. EstimateS 8.0 User's Guide published at http://purl. oclc.org/estimates.

CSIRO and Bureau of Meteorology (2007). Climate change in Australia. Office of Climate Change: Canberra, Australia.

Davies, S.J.J.F. (1976). Environmental variables and the biology of Australian arid zone birds (pp. 481-488). In: Frith, H.J. and Calaby, J.H. (eds), Proceedings XVI International Ornithological Congress. Australian Academy of Science: Canberra, Australia.

Davies, S.J.J.F. (1984). Nomadism as a response to desert 
conditions in Australia. Journal of Arid Environments 7: 183-195.

Davis, R.A. and Burbidge, A.H. (2008). The Elegant Parrot (Neophema elegans) in arid regions of Western Australia. Amytornis 1: 1-5.

Dell, J. and How, R.A. (1988). Vertebrate fauna. Records of the Western Australian Museum, Supplement 31: 38-66.

Dell, J. and How, R.A. (1992). Vertebrate fauna. Records of the Western Australian Museum, Supplement 40: 20-32.

Department of Environment, Water, Heritage and the Arts (2009). Australia's bioregions. Department of Environment, Water, Heritage and the Arts: Canberra, Australia; online at http://www.environment.gov. $\mathrm{au} /$ parks/nrs/science/ibra.html.

Dormann, C.F., McPherson, J.M., Araújo, M.B., Bivand, R., Bolliger, J., Carl, G., Davies, R.G., Hirzel, A., Jetz, W., Kissling, W.D., Kühn, I., Ohlemüller, R., Peres-Neto, P.R., Reineking, B., Schröder, B., Schurr, F.M. and Wilson, R. (2007). Methods to account for spatial autocorrelation in the analysis of species distributional data: a review. Ecography 30: 609-628.

Dray, S., Legendre, P. and Peres-Netoa, P.R. (2006). Spatial modelling: a comprehensive framework for principal coordinate analysis of neighbour matrices (PCNM). Ecological Modelling 196: 483-493.

Dunlop, M. and Brown, P.R. (2008). Implications of climate change for Australia's national reserve system - a preliminary assessment. CSIRO Sustainable Ecosystems, Report to the Department of Climate Change, and the Department of the Environment, Water, Heritage and the Arts: Canberra, Australia.

Faith, D.P., Minchin, P.R. and Belbin, L. (1987). Compositional dissimilarity as a robust measure of ecological distance. Vegetatio 69: 57-68.

Ferguson, K.M. and Ruddock, I. (2001). Mineral occurrences and exploration potential of the east Pilbara. Report 81, Western Australian Geological Survey: Perth, Australia.

Field, S.A., Tyre, A.T. and Possingham, H.P. (2002). Estimating bird species richness: how should repeat surveys be organised in time? Austral Ecology 27: 624-629.

Field, S.A., Tyre, A.T. and Possingham, H.P. (2005). Optimizing allocation of monitoring effort under economic and observational constraints. Journal of Wildlife Management 69: 473-482.

Fisher, C.D., Lindgren, E. and Dawson, W.R. (1972). Drinking patterns and behaviour of Australian desert birds in relation to their ecology and abundance. Condor 74: 111-136.

Flanders, A.A., Kuvlesky, W.P., Ruthven, D.C., Zaiglin, R.E., Bingham, R.L., Fulbright, T.E., Hernández, F. and Brennan, L.A. (2006). Effects of invasive exotic grasses on South Texas rangeland breeding birds. Auk 123: 171-182.

Ford, J. (1974). Speciation in Australian birds adapted to arid habitats. Emu 74: 161-168.

Franklin, D.C., Woinarski, J.C.Z. and Noske, R.A. (2000). Geographical patterning of species richness among granivorous birds in Australia. Journal of Biogeography 27: 829-842.

Freudenberger, D., Hodgkinson, K. and Noble, J.
(1997). Causes and consequences of landscape dysfunction in rangelands (pp. 63-77). In: Ludwig, J., Tongway, D., Freudenberger, D., Noble, J. and Hodgkinson, K. (eds), Landscape ecology, function and management: principles from Australian rangelands. CSIRO: Melbourne, Australia.

Gentilli, J. (1992). Numerical clines and escarpments in the geographical occurrence of avian species; and a search for relevant environmental factors. Ети 92: 129-140.

Gibson, D.B. and Cole, J.R. (1988). A biological survey of the northern Simpson Desert. Technical Report 40, Conservation Commission of the Northern Territory: [Darwin], Australia.

Holmes, R.T. and Sherry, T.W. (2001). Thirty-year bird population trends in an unfragmented temperate deciduous forest: importance of habitat change. Auk 118: 589-609.

How, R.A., Dell, J. and Cooper, N. (1991). Vertebrate fauna of the Abydos-Woodstock Reserve, northeast Pilbara. Records of the Western Australian Museum, Supplement 37: 78-125.

Ives, A.R. and Klopfer, E.D. (1997). Spatial variation in abundance created by stochastic temporal variation. Ecology 78: 1907-1913.

James, C.D., Landsberg, J. and Morton, S.R. (1995). Ecological functioning in arid Australia and research to assist conservation of biodiversity. Pacific Conservation Biology 2: 126-142.

Johnstone, R.E. (1983). Birds of the Hamersley Range National Park (pp. 12-25). In: Muir, B.G. (ed.), A faunal survey of the Hamersley Range National Park Western Australia 1980. Bulletin No. 1, National Parks Authority of Western Australia: Perth, Australia.

Johnstone, R.E. (2001). Checklist of the birds of Western Australia. Records of the Western Australian Museum, Supplement 63: 75-90.

Johnstone, R.E. (2008). Checklist of the birds of Western Australia. Western Australian Museum, [Accessed July 2009 at http://www.museum.wa.gov.au / collections/databases/fauna.asp].

Johnstone, R.E., Burbidge, A.H. and Stone, P. (2000). Birds of the southern Carnarvon Basin, Western Australia: distribution, status and historical changes. Records of the Western Australian Museum, Supplement 61: 371-448.

Kingston, M.B. (2005). Riparian and upslope influences on the regional avifauna of the semi-arid mulga lands of south west Queensland. PhD thesis, Griffith University: Nathan, Australia.

Kingston, M.B., Catterall, C.P. and Kordas, G.S. (2002). Use of riparian areas by terrestrial birds of the mulga lands - south west Queensland. Sunbird 32: 1-14.

Landsberg, J., James, C.D., Morton, S.R., Hobbs, T.J., Stol, J., Drew, A. and Tongway, H. (1997). The effects of artificial sources of water on rangeland biodiversity. Environment Australia Biodiversity Group and CSIRO Wildlife Ecology: Canberra, Australia.

Leavesley, A. (2008). The response of birds to the fire regimes of mulga woodlands in central Australia. PhD thesis, Australian National University: Canberra, Australia.

Legendre, P., Borcard, D., Blanchet, G. and Dray, S. (2009). 
PCNM: PCNM spatial eigenfunction and principal coordinate analyses. $R$ package version 1.9. R Foundation for Statistical Computing: Vienna, Austria.

Leighton, K.A. (2004). Climate (pp. 19-38). In: Van Vreeswyk, A.M.E., Payne, A.L., Leighton, K.A. and Hennig, P. (eds), An inventory and condition survey of the Pilbara Region, Western Australia. Technical Bulletin No. 92, Western Australian Department of Agriculture: Perth, Australia.

Lindenmayer, D.B., Wood, J.T. and MacGregor, C. (2009). Do observer differences in bird detection affect inferences from large-scale ecological studies? Emu 109: 100-106.

MacNally, R. (1996). A winter's tale: among-year variation in bird community structure in a southeastern Australian forest. Austral Ecology 21: 280-291.

Main, A.R. (1976). Adaptation of Australian vertebrates to desert conditions (pp. 101-131). In: Goodall, D.W. (ed.), Evolution of desert biota. University of Texas Press: Austin, U.S.A.

Maron, M., Lill, A., Watson, D.M. and MacNally, R. (2005). Temporal variation in bird assemblages: how representative is a one-year snapshot? Austral Ecology 30: 383-394.

May, J.E. and McKenzie, N.L. (2003). A biodiversity audit of Western Australia's biogeographical subregions in 2002. Department of Conservation and Land Management: Perth, Australia.

McKenzie, N.L., Rolfe, J.K. and Youngson, W.K. (1992). Vertebrate fauna. Records of the Western Australian Museum, Supplement 41: 37-64.

McKenzie, N.L., van Leeuwen, S. and Pinder, A.M. (2009). Introduction to the Pilbara Biodiversity Survey, 2002-2007. Records of the Western Australian Museum, Supplement 78: 3-89.

Miller, J.T., Andrew, R.A. and Maslin, B.R. (2002). Towards an understanding of variation in the mulga complex (Acacia aneura and relatives). Conservation Science Western Australia 4: 19-35.

Morton, S.R. (1990). The impact of European settlement on the vertebrate animals of arid Australia: a conceptual model. Proceedings of the Ecological Society of Australia 16: 201-213.

Ninox Wildlife Consulting (1992). Report: Marandoo project area vertebrate fauna assessments (1975-1991). Unpublished report to Enviroscan: Perth, Australia.

Paltridge, R. and Southgate, R. (2001). The effect of habitat type and seasonal conditions on fauna in two areas of the Tanami Desert. Wildlife Research 28: 247-260.

Pavey, C.R. and Nano, C.E.M. (2009). Bird assemblages of arid Australia: vegetation patterns have a greater effect than disturbance and resource pulses. Journal of Arid Environments 73: 634-642.

Pianka, H.D. and Pianka, E.R. (1970). Bird censuses from desert localities in Western Australia. Emu 70: 17-22.

R Development Core Team (2009). R: a language and environment for statistical computing. R Foundation for Statistical Computing: Vienna, Austria.

Recher, H.F. and Davis, W.E. (1997). Foraging ecology of a mulga bird community. Wildlife Research 24: 27-43.

Reid, J.R.W., Kerle, A. and Morton, S.R. (1993). Uluru fauna: the distribution and abundance of vertebrate fauna of Uluru (Ayers Rock-Mount Olga) National Park, N.T. Kowari 4: 1-152.

Robin, L., Heinsohn, R. and Joseph, L. (Eds) (2009). Boom and bust: bird stories for a dry continent. CSIRO Publishing: Collingwood, Australia.

Robinson, A.C., Casperson, K.D., Canty, P.D. and Macdonald, C.A. (1988). A biological survey of the Gawler Ranges South Australia in October 1985. National Parks and Wildlife Service: Adelaide, Australia.

Rodríguez-Ferraro, A. and Blake, J.G. (2008). Diversity patterns of bird assemblages in arid zones of northern Venezuela. Condor 110: 405-420.

Ruddock, I. (1999). Mineral occurrences and exploration potential of the west Pilbara. Report 70, Western Australian Geological Survey: Perth, Australia.

Schleucher, E. (1993). Life in extreme dryness and heat: a telemetric study of the behaviour of the Diamond Dove Geopelia cuneata in its natural habitat. Ети 93: 251-258.

Schneider, N.A. and Griesser, M. (2009). Influence and value of different water regimes on avian species richness in arid inland Australia. Biodiversity Conservation 18: 457-471.

Schodde, R. (1982). Origin, adaptation and evolution of birds in arid Australia (pp. 191-224). In: Barker, W.R. and Greenslade, P.J.M. (eds), Evolution of the flora and fauna of arid Australia. Peacock Publications: Adelaide, Australia.

Serventy, D.L. (1971). Biology of desert birds (pp. 287339). In: Farner, D.S. and King, J.R. (eds), Avian biology, Vol. 1. Academic Press: New York, U.S.A.

Shurcliff, K.S. (1980). Vegetation and bird community characteristics in an Australian arid mountain range. Journal of Arid Environments 3: 331-348.

Smyth, A., Friedel, M. and O'Malley, C. (2009). The influence of buffel grass (Cenchrus ciliaris) on biodiversity in an arid Australian landscape. Rangeland Journal 31: 307-320.

Start, A.N. (1986). Status and management of mulga in the Pilbara region of Western Australia (pp. 136-138). In: Sattler, P.J.S. (ed.), The mulga lands. The Royal Society of Queensland: Brisbane, Australia.

Storr, G.M. (1984). Birds of the Pilbara Region, Western Australia. Records of the Western Australian Museum, Supplement 16: 1-63.

Thackway, R. and Cresswell, I.D. (1995). An interim biogeographic regionalisation of Australia. Australian Nature Conservation Agency: Canberra, Australia.

Tieleman, B.I., Williams, J.B., Buschur, M.E. and Brown, C.R. (2003). Phenotypic variation of larks along an aridity gradient: are desert birds more flexible? Ecology 84: 1800-1815.

Trendall, A.F., Griffin, T.J. and Tyler, I.M. (1990). Pilbara Craton (pp. 128-194). In: Geology and mineral resources of Western Australia. Memoir 3, Geological Survey of Western Australian: Perth, Australia.

Tyre, A.T., Tenhumberg, B., Field, S.A., Niejalke, D., Parris, K. and Possingham, H.P. (2003). Improving precision and reducing bias in biological surveys: estimating false-negative error rates. Ecological Applications 13: 1790-1801. 
van Etten, E.J.B. (1998). Environmental factors affecting the boundary between mulga (Acacia aneura) and hummock grassland (Triodia spp.) communities. Master of Applied Science (Natural Resources) thesis, Curtin University of Technology: Perth, Australia.

Van Vreeswyk, A.M.E., Payne, A.L. and Leighton, K.A. (2004a). Pastoral resources and their management in the Pilbara region of Western Australia. Department of Agriculture, Western Australia: Perth, Australia.

Van Vreeswyk, A.M.E., Payne, A.L., Leighton, K.A. and Hennig, P. (2004b). An inventory and range condition survey of the Pilbara region, Western Australia. Technical
Bulletin 92, Western Australian Department of Agriculture: Perth, Western Australia.

Vellend, M., Lilley, P.L. and Starzomski, B.M. (2008). Using subsets of species in biodiversity surveys. Journal of Applied Ecology 45: 161-169.

Wiens, J.A. (1989). The ecology of bird communities. Cambridge Studies in Ecology. Cambridge University Press: Cambridge, Australia.

Withers, P.C. and Williams, J.B. (1990). Metabolic and respiratory physiology of an arid-adapted Australian bird, the Spinifex Pigeon. Condor 92: 961-969. 
APPENDIX 1.

Frequency of encountering bird species at 297 sites in the Pilbara. Nocturnal species are indicated with an ' $N$ '; these species were excluded from analyses because we did not sample at night at most sites. Names and order follow Johnstone $(2001,2008)$.

\begin{tabular}{|c|c|c|}
\hline Common name & Scientific name & $\begin{array}{l}\text { Number of sites } \\
\text { where recorded }\end{array}$ \\
\hline Emu & Dromaius novaehollandiae & 33 \\
\hline Stubble Quail & Coturnix pectoralis & 5 \\
\hline Brown Quail & Coturnix ypsilophora & 7 \\
\hline Plumed Whistling Duck & Dendrocygna eytoni & 1 \\
\hline Black Swan & Cygnus atratus & 1 \\
\hline Grey Teal & Anas gracilis & 1 \\
\hline Pacific Black Duck & Anas superciliosa & 2 \\
\hline White-necked Heron & Ardea pacifica & 1 \\
\hline Rufous Night Heron & Nycticorax caledonicus & 1 \\
\hline Australian White Ibis & Threskiornis molucca & 2 \\
\hline Black-shouldered Kite & Elanus caeruleus & 10 \\
\hline Black-breasted Buzzard & Hamirostra melanosternon & 2 \\
\hline Black Kite & Milvus migrans & 2 \\
\hline Whistling Kite & Haliastur sphenurus & 38 \\
\hline Brahminy Kite & Haliastur indus & 2 \\
\hline Brown Goshawk & Accipiter fasciatus & 7 \\
\hline Collared Sparrowhawk & Accipiter cirrocephalus & 5 \\
\hline Little Eagle & Aquila morphnoides & 9 \\
\hline Wedge-tailed Eagle & Aquila audax & 32 \\
\hline White-bellied Sea-Eagle & Haliaeetus leucogaster & 2 \\
\hline Spotted Harrier & Circus assimilis & 32 \\
\hline Swamp Harrier & Circus approximans & 1 \\
\hline Brown Falcon & Falco berigora & 84 \\
\hline Australian Kestrel & Falco cenchroides & 78 \\
\hline Australian Hobby & Falco longipennis & 10 \\
\hline Peregrine Falcon & Falco peregrinus & 1 \\
\hline Australian Bustard & Ardeotis australis & 62 \\
\hline Red-chested Button-quail & Turnix pyrrhothorax & 4 \\
\hline Little Button-quail & Turnix velox & 75 \\
\hline Common Greenshank & Tringa nebularia & 1 \\
\hline Bush Stone-curlew & Burhinus grallarius & 7 \\
\hline Black-fronted Dotterel & Charadrius melanops & 4 \\
\hline Oriental Plover & Charadrius veredus & 1 \\
\hline Australian Pratincole & Stiltia isabella & 2 \\
\hline Gull-billed Tern & Sterna nilotica & 2 \\
\hline White-winged Black Tern & Sterna leucoptera & 1 \\
\hline Common Bronzewing & Phaps chalcoptera & 14 \\
\hline Crested Pigeon & Ocyphaps lophotes & 145 \\
\hline Spinifex Pigeon & Geophaps plumifera & 94 \\
\hline Diamond Dove & Geopelia cuneata & 168 \\
\hline Peaceful Dove (Zebra Dove) & Geopelia striata & 29 \\
\hline
\end{tabular}




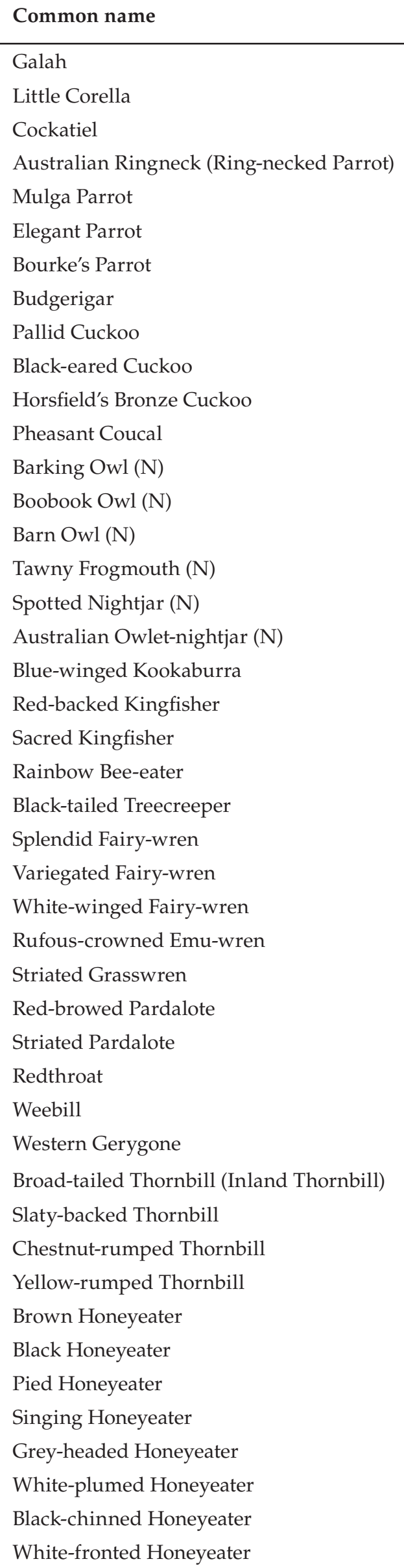

\section{Scientific name}

Cacatua roseicapilla

Cacatua sanguinea

Nymphicus hollandicus

Platycercus zonarius

Platycercus varius

Neophema elegans

Neophema bourkii

Melopsittacus undulatus

Cuculus pallidus

Chrysococcyx osculans

Chrysococcyx basalis

Centropus phasianinus

Ninox connivens

Ninox novaeseelandiae

Tyto alba

Podargus strigoides

Eurostopodus argus

Aegotheles cristatus

Dacelo leachii

Todiramphus pyrrhopygius

Todiramphus sanctus

Merops ornatus

Climacteris melanura

Malurus splendens

Malurus lamberti

Malurus leucopterus

Stipiturus ruficeps

Amytornis striatus

Pardalotus rubricatus

Pardalotus striatus

Pyrrholaemus brunneus

Smicrornis brevirostris

Gerygone fusca

Acanthiza apicalis

Acanthiza robustirostris

Acanthiza uropygialis

Acanthiza chrysorrhoa

Lichmera indistincta

Certhionyx niger

Certhionyx variegatus

Lichenostomus virescens

Lichenostomus keartlandi

Lichenostomus penicillatus

Melithreptus gularis

Phylidonyris albifrons
Number of sites where recorded 138 


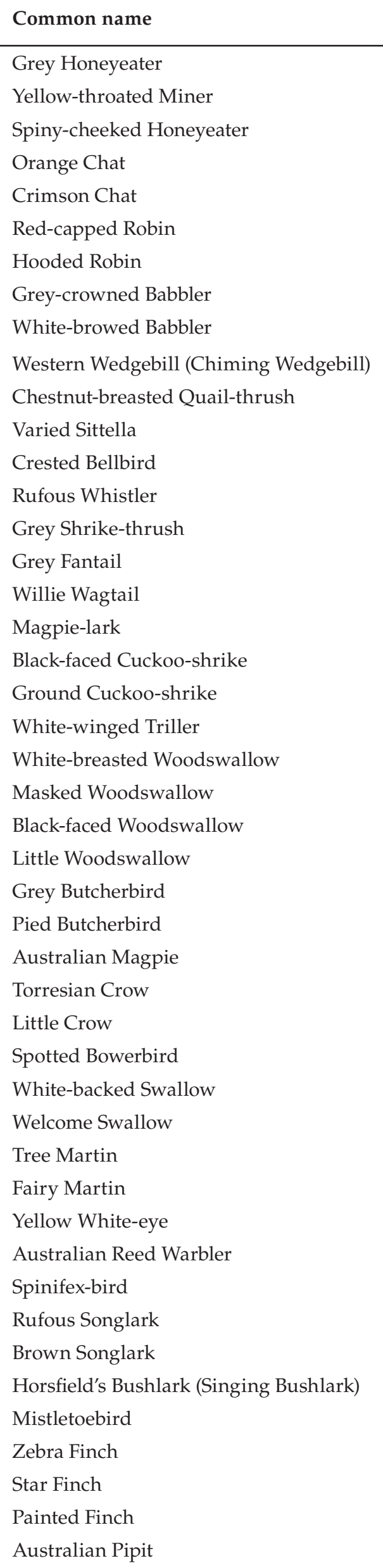

\section{Scientific name}

Lacustroica whitei

Manorina flavigula

Acanthagenys rufogularis

Epthianura aurifrons

Epthianura tricolor

Petroica goodenovii

Petroica cucullata

Pomatostomus temporalis

Pomatostomus superciliosus

Psophodes occidentalis

Cinclosoma castaneothorax

Daphoenositta chrysoptera

Oreoica gutturalis

Pachycephala rufiventris

Colluricincla harmonica

Rhipidura fuliginosa

Rhipidura leucophrys

Grallina cyanoleuca

Coracina novaehollandiae

Coracina maxima

Lalage tricolor

Artamus leucorynchus

Artamus personatus

Artamus cinereus

Artamus minor

Cracticus torquatus

Cracticus nigrogularis

Cracticus tibicen

Corvus orru

Corvus bennetti

Ptilonorhynchus maculatus

Cheramoeca leucosternus

Hirundo neoxena

Hirundo nigricans

Hirundo ariel

Zosterops luteus

Acrocephalus australis

Eremiornis carteri

Cincloramphus mathewsi

Cincloramphus cruralis

Mirafra javanica

Dicaeum hirundinaceum

Taeniopygia guttata

Neochmia ruficauda

Emblema pictum

Anthus australis
Number of sites where recorded 1 155 